\title{
Studi Kelayakan Sumber Daya Air Baku Pulau Bintan - Tinjauan Aspek Kuantitas dan Kualitas
}

\author{
Dyah Marganingrum ${ }^{1}$ \\ Pusat Penelitian Geoteknologi-LIPI, Bandung, Indonesia

\section{Nyoman Sumawijaya} \\ Pusat Penelitian Geoteknologi-LIPI, Bandung, Indonesia
}

\section{Arief Rachmat}

Pusat Pemanfaatan dan Inovasi IPTEK-LIPI, Bandung, Indonesia

Artikel Masuk : 18 Oktober 2019

Artikel Diterima : 20 April 2020

Tersedia Online : 30 April 2020

\begin{abstract}
Abstrak: Kelayakan sumber air baku didasarkan atas tiga aspek, yaitu kuantitas, kualitas, dan kontinuitas. Penelitian ini bertujuan untuk menilai kelayakan air baku di Pulau Bintan pada aspek kuantitas dan kualitasnya. Metode penelitian yang digunakan adalah analisis komprehensif fungsi hidrologi dan hidrogeologi serta kualitas air. Hasil studi menunjukkan bahwa kelimpahan air hujan di lokasi studi tidak tersimpan maksimal sebagai air tanah karena keterbatasan luas daerah tangkapan serta kapasitas simpan media akuifer yang didominasi oleh satuan batuan dengan tingkat kelulusan rendah sampai sedang $(80 \%)$. Hidrogeologi lokasi studi juga didominasi oleh daerah akuifer produktivitas rendah setempat berarti $(70 \%)$ yang ditunjukkan dengan lapisan akuifer yang dangkal. Oleh karena itu, keberadaan waduk atau storage menjadi sangat penting. Hasil perhitungan tahun 2017 menunjukkan bahwa produksi air baku PDAM Tirta Kepri sebesar 3.521.855 $\mathrm{m}^{3} /$ tahun. Sementara kebutuhan masyarakat di Pulau Bintan pada tahun yang sama sebesar $7.957 .803 \mathrm{~m}^{3} / \mathrm{tahun}$. Analisis aspek kualitas menunjukkan bahwa kualitas air sumur tercemar ringan (WQI = 0,59), sedangkan air permukaan tercemar sedang (WQI $=1,01)$. Parameter yang memberikan perbedaan dari kedua sumber tersebut adalah kandungan besi. Hasil analisis diagram Gibbs menunjukkan adanya proses pelapukan oleh air hujan yang mengikis permukaan tanah bekas tambang bauksit dan melarutkan besi serta mengalir bersama air limpasan dan masuk ke dalam waduk-waduk. Potensi pencemaran oleh besi yang tinggi akan meningkat sering ditetapkannya Pulau Bintan sebagai Kawasan Ekonomi Khusus. Kegiatan industri dan jasa akan memicu terjadinya hujan asam yang berdampak pada penurunan nilai $\mathrm{pH}$ hujan dan proses pelarutan besi pada batuan serta permukaan tanah akan semakin meningkat.
\end{abstract}

Kata Kunci: akuifer; digram Gibb's; kuantitas; kualitas; waduk

Abstract: The raw water feasibility is based on three aspects, such as quantity, quality, and continuity. This study aims to assess the feasibility of raw water on Bintan Island in quantity

\footnotetext{
${ }^{1}$ Korespondensi Penulis: Pusat Penelitian Geoteknologi-LIPI, Bandung, Indonesia Email: dmarganingrum@yahoo.com
} 


\section{Studi Kelayakan Sumber Daya Air Baku Pulau Bintan - Tinjauan Aspek Kuantitas dan Kualitas}

and quality terms The method used is a comprehensive analysis of hydrological and hydrogeological functions and water quality. The result of study shows that rainwater abundance in study location is not optimally stored as ground water due to limited catchment area and storage capacity of aquifer media which are dominated by rock units with low to moderate graduation rates (80\%). The hydrogeology of study site is also dominated by local low productivity aquifer areas (70\%) which are indicated by shallow aquifer layers. Therefore, the existence of reservoirs or storage is very important. The calculations results in 2017 show that raw water production of PDAM Tirta Kepri is 3,521,855 $\mathrm{m}^{3} /$ year. While the community needs on Bintan Island in the same year amounted to 7,957,803 $\mathrm{m}^{3} /$ year. Quality aspect analysis shows that the quality of well is lightly polluted (WQI $=0.59$ ), while surface water is moderately polluted (WQI $=1.01$ ). The parameter that gives the difference from two sources is iron content. Gibbs diagram analysis results show the weathering process by rainwater which erodes the land surface of bauxite mine and dissolves iron and flows along with runoff and into reservoirs. The potential for high iron pollution will increase often as Bintan Island is designated as a Special Economic Zone. Industrial and service activities will trigger acid rain which will cause a decrease in the value of rain $\mathrm{pH}$ and the process of dissolving iron on rocks and soil surfaces will increase.

Keywords: aquifer; Gibb’s diagram; quality; quantity; reservoir

\section{Pendahuluan}

Pengembangan wilayah menuntut penyediaan sarana dan prasarana yang mendukungnya dan salah satu di antaranya adalah air baku, baik air baku untuk air minum, pertanian (irigasi), perikanan, pariwisata, Pembangkit Listrik Tenaga Air (PLTA) atau kebutuhan lainnya. Berdasarkan hierarkinya, pemenuhan kebutuhan air baku untuk air minum lebih tinggi derajatnya, sehingga persyaratan kualitasnya pun lebih tinggi daripada persyaratan kualitas untuk kebutuhan lainnya, sebagaimana diatur dalam Peraturan Pemerintah (PP) Nomor 82 Tahun 2001 tentang Pengelolaan Kualitas Air dan Pengendalian Pencemaran Air. Atas dasar ini, studi ini difokuskan pada kelayakan air baku untuk memenuhi kebutuhan air minum. Terminologi air minum dalam penelitian ini adalah air bersih yaitu air baku untuk memenuhi kebutuhan rumah tangga/mandi cuci kakus MCK) dan air minum melalui proses pengolahan (dimasak) terlebih dahulu. Persyaratan utama sumber air yang layak digunakan sebagai air baku meliputi tiga aspek yaitu kuantitas, kualitas, dan kontinuitas (Marganingrum, 2013).

Studi ini dilakukan di Pulau Bintan yang merupakan salah satu pulau terbesar di wilayah Provinsi Kepulauan Riau dengan luas daratan sebesar 4.303,3 km² (Sembiring, 2008). Kondisi sumber daya air di Pulau Bintan memiliki kerentanan. Faktor kerentanan tersebut dipengaruhi karena catchment area yang terbatas (faktor intrinsik) serta pengaruh perubahan iklim, intrusi air laut, ataupun karena pemanfaatan yang tidak terkendali (faktor ekstrinsik) (Marganingrum \& Sudrajat, 2018; Masterson et al., 2013; Utomo, Marganingrum, Rusydi, Purwoarminta, \& Ningrum, 2017). Selain kerentanan yang bersifat intrinsik maupun ekstrinsik, Pulau Bintan juga merupakan wilayah bekas tambang terbuka (open mining) bauksit yang sangat luas. Tambang terbuka berdampak pada lapisan tanah yang apabila tidak dilakukan konservasi dan remediasi akan berdampak terhadap kuantitas dan kualitas sumber daya air (Rusli \& Fauzielly, 2016), baik air tanah maupun air permukaan, sementara lapisan pembawa air tanah (aquifer) di Pulau Bintan sangat terbatas. Ketersediaan air yang terbatas ini menjadi lebih krusial ketika Pulau Bintan ditetapkan sebagai salah satu kawasan Free Trade Zone (FTZ) bersama pulau Batam dan Karimun (Hardiansyah, 2016). Penatapan kawasan FTZ ini akan berimplikasi terhadap peningkatan kebutuhan air baku. Oleh karena itu, perlu dilakukan penelitian terhadap kelayakan sumber 
daya air di Pulau Bintan secara menyeluruh, baik kuantitas maupun kualitas, agar dapat melakukan upaya pengendalian dan mitigasi terhadap kondisi yang tidak diharapkan.

Santoso (2015) melakukan studi daya dukung sumber daya air di Pulau Bintan yang membandingkan antara kebutuhan dari semua sektor dan ketersediaannya. Hasil yang diperoleh adalah bahwa ketersediaan air di Pulau Bintan jauh lebih besar (2.431.819.623 $\mathrm{m}^{3} /$ th) dari kebutuhannya (67.726.595 $\left.\mathrm{m}^{3} / \mathrm{th}\right)$, dengan sektor perikanan adalah jenis kebutuhan yang terbesar. Namun penelitian Santoso (2015) tersebut belum memperhatikan aspek kualitasnya. Rusli \& Fauzielly (2016) melakukan studi kualitas air di Pulau Bintan untuk mengetahui pengaruh bauksit terhadap air tanah yang dikaitkan dengan kajian batuan dan sedimennya. Namun studi ini hanya menggunakan tiga data (dua sumur uji dan satu lahan bekas tambang). Ketiga lokasi sampling berada di daerah pantai, sehingga akan sulit membedakan antara penurunan kualitas karena instrusi air laut atau karena faktor lainnya (seperti faktor geologi atau aktivitas manusia di darat). Penelitian sebelumnya mengkaji kualitas air di wilayah pesisir Pulau Bintan terhadap ekosistemnya (Budiyanto, Arbi, \& Suratno, 2019; Meirinawati \& Muchtar, 2017) dan juga kajian kualitas air di lahan bekas tambang (Apriadi \& Ashari, 2018; Aryani \& Apriadi, 2018; Putra et al., 2018; Rusli \& Fauzielly, 2016). Namun penelitian tersebut belum mengkaji kualitas air secara menyeluruh di seluruh Pulau Bintan untuk mendapatkan potensi ketersediaan air baku (khususnya air baku untuk air minum atau sektor rumah tangga) yang berkelanjutan. Berbeda dari penelitian sebelumnya penelitian ini akan fokus pada kajian komprehensif terkait kelayakan sumber daya air di Pulau Bintan. Penelitian ini bertujuan untuk menilai kelayakan air baku di Pulau Bintan pada aspek kuantitas dan kualitasnya. Aspek kuantitas penting mengingat Pulau Bintan merupakan pulau kecil dengan tingkat pertumbuhan ekonomi yang pesat sebagai kawasan FTZ, sedangkan kualitas sumber daya airnya sangat rentan, karena Pulau Bintan sebagai kawasan tambang, khususnya bauksit yang dapat mencemari sumber daya air yang memang sudah sangat terbatas. Oleh karena itu aspek kuantitas dan kualitas perlu dipertimbangkan secara terintegrasi agar sumber daya air di Pulau Bintan dapat berkelanjutan.

\section{Metode Penelitian}

\section{Kerangka Pikir}

Ketersediaan air, khususnya di pulau kecil akan sangat tergantung pada air hujan dan kapasitas daerah tangkapan (catchment area). Oleh karena itu, mengetahui jumlah curah hujan dan kapasitas daerah tangkapan sangat penting untuk mengetahui potensi ketersediaan air baku dari aspek kuantitasnya. Selain menghitung dan menganalisis data curah hujan, perlu juga melakukan telaah aspek hidrogeologi bawah permukaan wilayah studi, sedangkan aspek kualitas ditentukan oleh dua faktor yaitu faktor alami atau karena aktivitas pencemaran dari berbagai sumber.

Material terlarut (solutes) dalam air secara alami menggambarkan hasil dari sejumlah proses pelarutan dan pengendapan karena aliran air hujan di suatu wilayah (Hem, 1989). Air tanah berasal dari air hujan yang setelah jatuh di permukaan tanah, mengalir di permukaan dan meresap ke dalam tanah kemudian terakumulasi dalam zona jenuh (air tanah). Dengan demikian, maka dapat dipahami bahwa kualitas unsur-unsur yang terkandung dalam air tanah di suatu wilayah dipengaruhi oleh kondisi lingkungan dan geologi daerah setempat yang dilalui air hujan menuju zona jenuh (air tanah). Untuk memahami kondisi hidrokimia air tanah di Pulau Bintan dilakukan telaah terhadap kondisi geologi dan analisa laboratorium terhadap sejumlah sampel air yang diambil di lapangan. 


\section{Metode Analisis}

Tahapan analisis yang dilakukan dalam penelitian ini terdiri dari tahapan pengumpulan data yang meliputi: (1) survei lapangan untuk memahami kondisi fisik wilayah studi; (2) pengumpulan data sekunder meliputi data geologi, data kependudukan (Badan Pusat Statistik/BPS), data pemantauan kualitas air (Dinas Lingkungan Hidup/DLH), dan data penyediaan air minum (PDAM Tirta Kepri); dan (3) pengumpulan data primer yang dilakukan dengan pengambilan conto air sebanyak enam puluh tiga titik dengan rincian empat puluh delapan titik adalah air sumur gali, tiga belas titik adalah air permukaan, dan dua titik air hujan (Gambar 1). Tahapan ini dilakukan dengan cara pengamatan dan pengukuran parameter fisika-kimia air yang dibedakan atas: (a) pengukuran di lapangan (insitu) meliputi tinggi muka air, $\mathrm{pH}$, temperatur, dan nilai DHL; dan (b) analisis laboratorium dengan menggunakan semua parameter acuan untuk air bersih di Laboratorium Kualitas Air Program Studi Teknik Lingkungan Institut Teknologi Bandung (ITB).

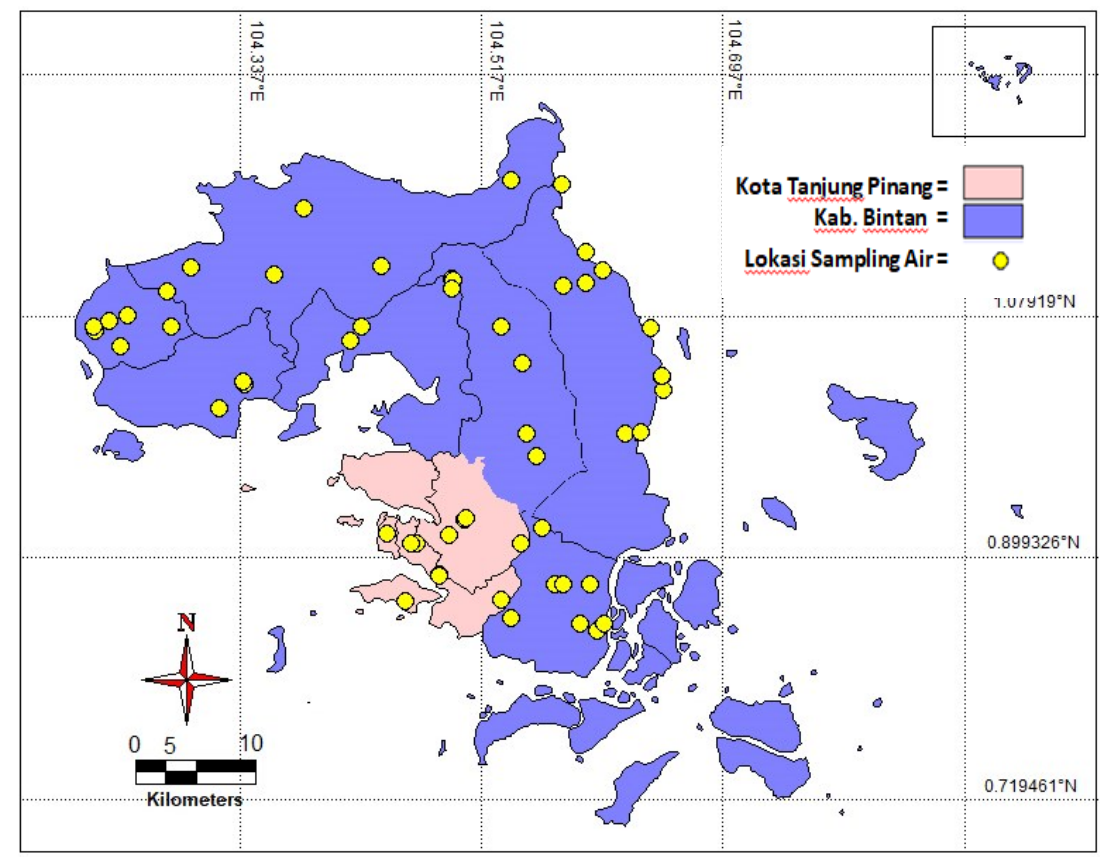

\section{Gambar 1. Distribusi Lokasi Sampling Air di Lokasi Studi}

Selanjutnya tahapan analisis dilakukan melalui uji hidrogeologi untuk mengetahui penyebaran akuifer serta kondisi bawah permukaan menggunakan metoda konfigurasi elektroda Schlumberger. Metode ini dipilih dengan alasan: (1) umum atau sering digunakan; (2) tidak terlalu sensitif terhadap adanya perubahan lateral (arus mempunyai jarak yang lebih besar dibandingkan dengan elektroda potensialnya); dan (3) waktu pengerjaannya tidak terlalu lama untuk wilayah yang cukup luas. Data yang diperoleh akan merefleksikan sifat fisis batuan bawah permukaan pada suatu kedalaman tertentu yang berasosiasi dengan jarak/konfigurasi elektrodanya. Data dari hasil pengukuran lapangan berupa besarnya arus dan beda potensial pada susunan elektroda dengan $A B / 2$ dan $M N / 2$ tertentu. Untuk konfigurasi elektroda Schlumberger tahanan jenis semua pa diperoleh dengan persamaan (1), sebagai berikut: 


$$
\rho_{\mathrm{a}}=\frac{\pi(\mathrm{AB} / 2)^{2}-(\mathrm{MN} / 2)^{2}}{2(\mathrm{MN} / 2)} \frac{\Delta \mathrm{V}}{\mathrm{I}}
$$

Keterangan: $\rho_{\mathrm{a}}=$ tahanan jenis semu (ohm.meter); $\Delta \mathrm{V}=$ beda potensial (mili Volt); $\mathrm{I}=$ kuat arus (mili Ampere); $\mathrm{AM}=$ jarak eletroda arus; dan $\mathrm{MN}=$ jarak elektroda potensial.

Satu titik mempunyai nilai $\rho_{\mathrm{a}}$ banyak tergantung jarak lintasan bentangannya. Setelah memperoleh nilai $\rho_{\mathrm{a}}$ kemudian dengan menggunakan software IPI2win dari Moscow University, data tersebut kemudian diolah untuk mendapat lapisan $\rho_{a}$. Setiap lapisan batuan atau tanah dengan material tertentu memiliki tahanan jenis yang berbeda (Tabel 1). Dari setiap titik VES kemudian digabungkan untuk memperoleh penampang bawah permukaan bumi. Pada studi ini, uji geolistrik di Pulau Bintan dilakukan pada empat lintasan.

Analisis selanjutnya yaitu analisis kualitas air yang dilakukan dengan menggunakan pendekatan metode Water Quality Index (WQI). Penelitian Marganingrum (2013) menunjukkan bahwa metode WQI lebih baik daripada metode Indeks Pencemaran (IP) yang tercantum dalam Keputusan Menteri Lingkungan Hidup Nomor 115 Tahun 2003. Metode WQI adalah sebuah metode penilaian kualitas air dalam bentuk indeks yang mudah dan sederhana namun dapat memberikan informasi yang baik dalam mendeskripiskan kualitas air (Marganingrum, 2013; Ochir \& Davaa, 2011). Metode WQI dirumuskan dengan persamaan (2), sebagai berikut.

$$
W Q I=\frac{\sum \frac{C_{i}}{P L_{i}}}{n}
$$

Keterangan: WQI = indeks kualitas air (water quality index); $\mathrm{Ci}=$ konsentrasi variabel ke-i; $\mathrm{PLi}=$ standar baku yang diijinkan untuk variabel ke-i; dan $\mathrm{n}=$ jumlah variabel.

Nilai WQI kemudian diklasifikasikan menggunakan kriteria yang ditampilkan pada Tabel 2 sesuai kelasnya agar dapat dilakukan pengendalian atau upaya pencegahan dan konservasi.

Tabel 1. Nilai Resistivity

\begin{tabular}{lr}
\hline \multicolumn{1}{c}{ Material } & Resistivity (Ohm.m) \\
\hline Batuan Beku dan Metamorfosa & $5 \times 10^{3}-10^{6}$ \\
Granit & $10^{3}-10^{6}$ \\
Basalt & \\
Batuan Sedimen & $8-4 \times 10^{3}$ \\
Sandstone & $20-2 \times 10^{3}$ \\
Shale & $50-4 \times 10^{3}$ \\
batu gamping & \\
Soil dan air & $8-4 \times 10^{3}$ \\
Lempung & $10-800$ \\
Alluvium & $10-100$ \\
Groundwater & 0,2 \\
Sea Water & \\
\hline Sumber: Dut
\end{tabular}

Sumber: Duvendack et al. 2011

Analisis selanjutnya yaitu analisis secara komprehensif dengan cara mengintegrasikan faktor kualitas air dengan faktor iklim (curah hujan), kondisi 
geologi/tanah, data akuifer, dan jumlah kebutuhan air minum untuk memberikan rekomendasi upaya pengendalian di masa yang akan datang terkait dengan penetapan wilayah studi sebagai Kawasan Ekonomi Khusus (KEK) dan Free Trade Zone (FTZ).

Tabel 2. Klasifikasi Kualitas Air Permukaan

\begin{tabular}{|c|c|c|c|}
\hline \multirow{2}{*}{ Nilai WQI } & \multicolumn{2}{|c|}{ Kualitas air } & \multirow[t]{2}{*}{ Rekomendasi } \\
\hline & Tingkat & Kelas & \\
\hline $\mathrm{WQI} \leq 0,30$ & 1 & Sangat bersih & $\begin{array}{l}\text { Tidak diperlukan pengolahan. Sesuai untuk } \\
\text { berbagai macam penggunaan }\end{array}$ \\
\hline $0,31 \leq \mathrm{WQI} \leq 0,89$ & 2 & Bersih & $\begin{array}{l}\text { Untuk minum dan pertanian perlu pengolahan, } \\
\text { untuk perikanan tanpa pengolahan }\end{array}$ \\
\hline $0,90 \leq \mathrm{WQI} \leq 2,49$ & 3 & $\begin{array}{l}\text { Tercemar } \\
\text { ringan }\end{array}$ & $\begin{array}{l}\text { Tidak sesuai untuk minum dan pertanian, jika } \\
\text { tidak ada pilihan maka perlu dilakukan } \\
\text { pengolahan untuk kedua pebutuhan tersebut. } \\
\text { Tidak memerlukan pengolahan jika digunakan } \\
\text { untuk peternakan, rekreasi, dan tujuan olah raga }\end{array}$ \\
\hline $2,50 \leq \mathrm{WQI} \leq 3,99$ & 4 & $\begin{array}{l}\text { Tercemar } \\
\text { sedang }\end{array}$ & $\begin{array}{l}\text { Dapat digunakan untuk irigasi dan keperluan } \\
\text { industri dengan pengolahan terlebih dahulu }\end{array}$ \\
\hline $4,00 \leq \mathrm{WQI} \leq 5,99$ & 5 & Tercemar berat & $\begin{array}{l}\text { Hanya dapat digunakan untuk kepentingan } \\
\text { industri berat yang tanpa kontak bandan setelah } \\
\text { dilakukan pengolahan tertentu. }\end{array}$ \\
\hline $\mathrm{WQI} \geq 6,00$ & 6 & Kotor & $\begin{array}{l}\text { Tidak sesuai untuk berbagai kebutuhan dan biaya } \\
\text { pengolahan sangat ekstensif (mahal) }\end{array}$ \\
\hline
\end{tabular}

Sumber: Ochir \& Davaa, 2011

\section{Hasil dan Pembahasan}

Potensi ketersediaan air di Pulau Bintan tidak terlepas dari curah hujan yang turun sepanjang tahun di lokasi studi. Berdasarkan pola hujannya, Pulau Bintan adalah termasuk wilayah dengan tipe hujan equatorial (Tjasyono \& Bannu, 2003; Trenberth, Caron, Stepaniak, \& Worley, 2000), artinya dalam satu tahun terdapat dua kali puncak hujan. Berdasarkan hasil analisis data hujan tahun 1996 sampai den 2017, puncak hujan terdapat pada bulan April/Mei dan November/Desember dengan hujan tahunan rata-rata sebesar $3457 \mathrm{~mm}$ (Gambar 2). Analisis terhadap data hujan menjadi sangat penting dalam pengelolaan sumber daya air, khususnya di wilayah dengan daerah tangkapan yang sangat terbatas.

Curah hujan yang berlimpah di lokasi studi (Pulau Bintan) seharusnya diimbangi dengan kapasitas penyimpanan yang memadai (baik yang bersifat alami atau buatan), agar volume air hujan yang ditampung dapat digunakan untuk memenuhi berbagai kebutuhan (Sallata, 2017; Silvia \& Safriani, 2018). Secara alami, kondisi kapasitas penyimpanan Pulau Bintan terhadap hujan yang jatuh cukup rendah. Hal ini terkait dengan formasi geologi dan jenis tanah yang ada di lokasi studi (Setiady \& Faturachman, 2004; Sukiyah, Isnaniawardhani, Sudradjat, \& Erawan, 2018). Formasi geologi Pulau Bintan terdiri atas: (1) granit Tipe $\mathrm{S}$ berumur Trias yang berada setempat dibagian barat dan utara Pulau Bintan; (2) endapan aluvium yang terdiri dari lempung, pasir dan breksi pasiran, umumnya menempati daerah sempit di dataran pantai dan muara sungai yang terletak di sisi barat bagian utara; (3) formasi Goungon yang berumur Tersier - Kuarter terdiri dari batu pasir tufan, batu lanau pasiran, dan tuf dasitan melampar luas dibagian tengah; dan (4) satuan andesit porfir setempat di bagian timur.

Pulau Bintan juga didominasi oleh tanah dengan komposisi Hapludox dan Kandiudults dari pelapukan batuan granit seluas $77,8 \%$ dari luas total (Narulita, 
Djuwansyah, Sumawijaya, Marganingrum, Ningrum, \& Rahayu, 2018; Setiady \& Faturachman, 2016). Sumber lain mengatakan bahwa Pulau Bintan memiliki jenis tanah organosol, clay humik, podsol, podsolik kuning, dan latosol (Irawan \& Yudono, 2014; Sembiring, 2008). Jenis tanah di Pulau Bintan ini umumnya berwarna kuning kecoklatan hingga merah, memiliki penampang tanah yang dalam dengan kenaikkan fraksi liat seiring peningkatan kedalaman, miskin organik dan unsur hara. Tanah jenis ini juga dicirikan dengan adanya akumulasi liat pada horizon bawah permukaan sehingga mengurangi daya resap air dan meningkatkan aliran permukaan serta erosi tanah (Prasetyo \& Suriadikarta, 2006).

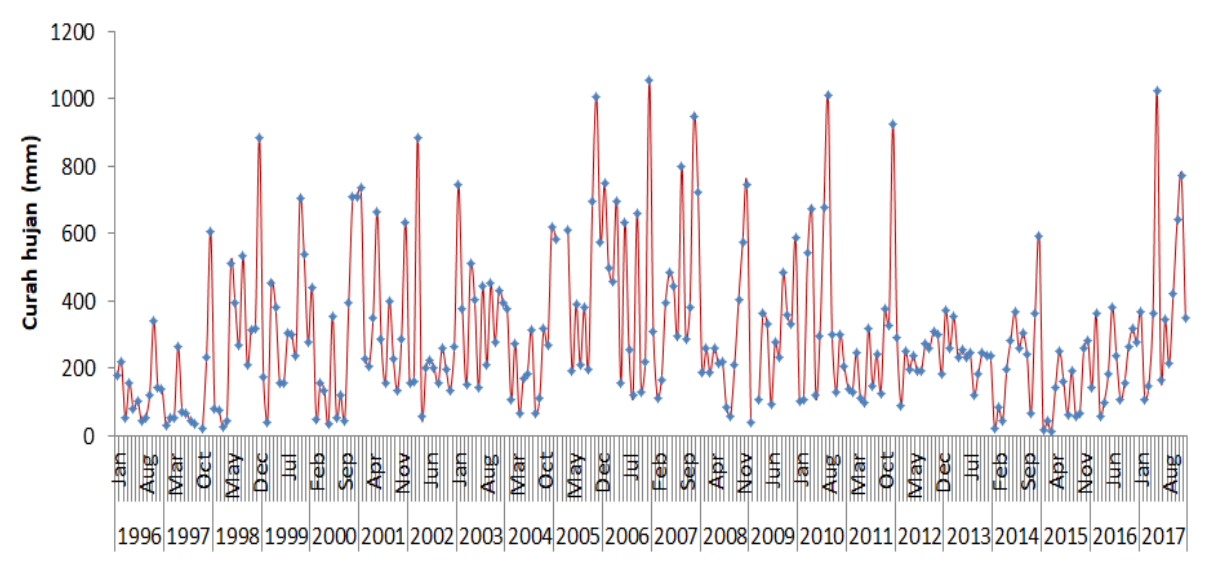

(a)

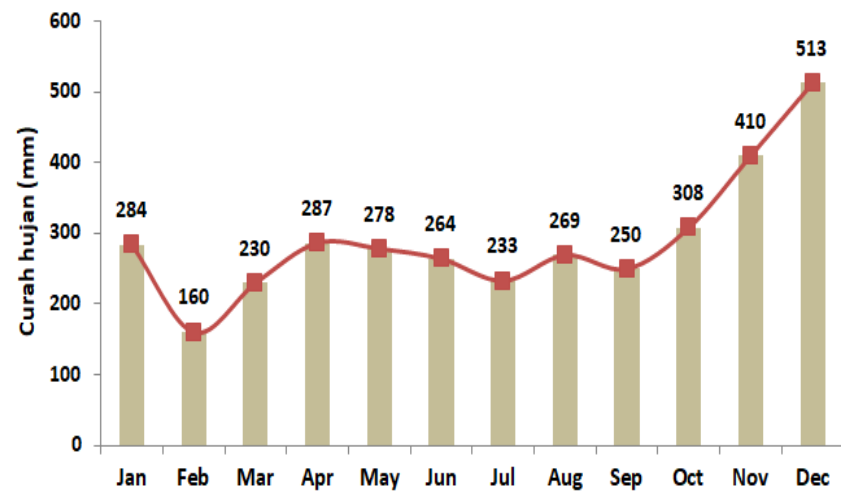

(b)

\section{Gambar 2. Pola Hujan Equatorial di Pulau Bintan Berdasarkan (a) Hasil Perhitungan Data Hujan 1996-2017 dan (b) Berdasarkan Data per Bulan pada Tahun 2017}

Tanah memiliki dua fungsi utama yaitu: (1) sebagai matrik tempat akar tumbuhan berjangkar dan air tanah tersimpan; (2) sebagai sumber unsur hara (Arsad, 2010). Formasi geologi dan jenis tanah seperti yang telah disebutkan menyebabkan lahan di Pulau Bintan memiliki kapasitas penyimpanan air tanah yang terbatas dan tidak dapat digunakan sebagai lahan basah untuk pertanian (sawah), meskipun curah hujan di wilayah ini mencukupi (Gambar 3).

Argumentasi mengenai akuifer penyimpanan air tanah yang terbatas di lokasi studi, diperkuat dengan melakukan uji geolistrik. Gambar 4 adalah empat lintasan uji geolistrik dan Gambar 5 adalah hasil interpretasi dari setiap lintasan. Pada umumnya Pulau Bintan didominasi Batulempung, serpih, batupasir lempungan, batupasir kwarsa dan konglomerat 
dengan tingkat kelulusan rendah sampai sedang (hampir 80\%) dan lapisan pembawa air (akuifer) yang utama di daerah studi adalah pasir serta lapukan batuan.

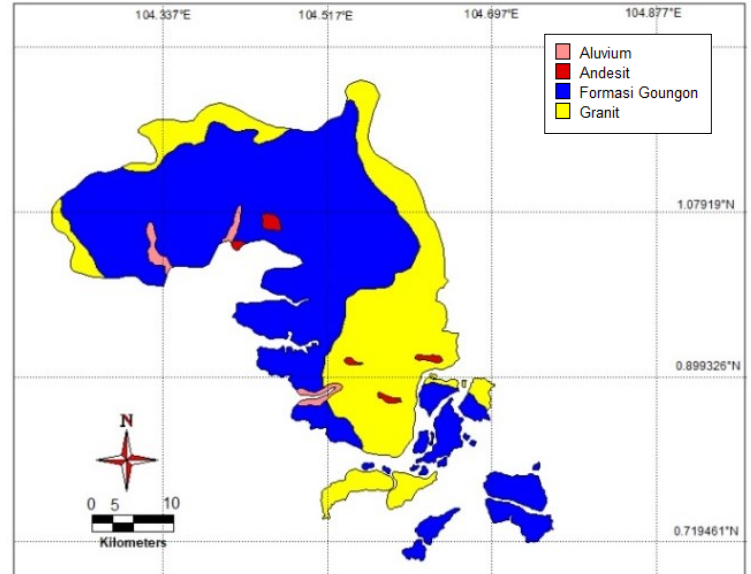

(a)

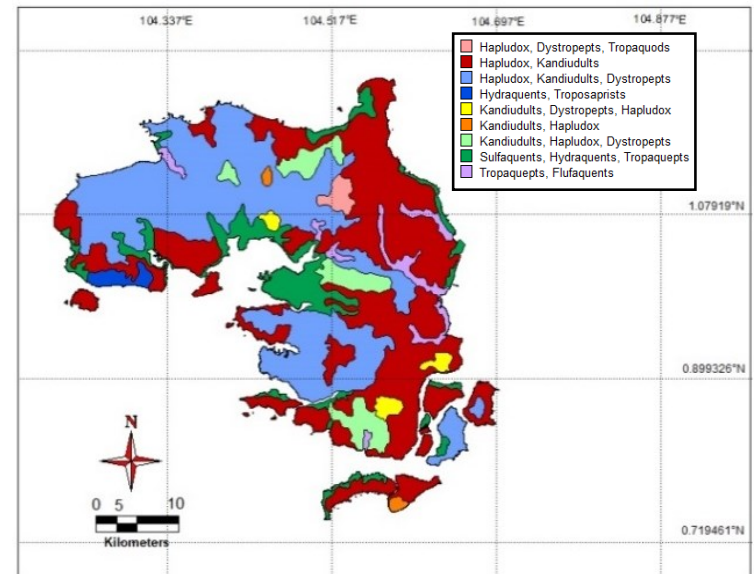

(b)

\section{Gambar 3. (a) Formasi Geologi dan (b) Komposisi Tanah di Pulau Bintan}

Berdasarkan peta hidrogeologi, Pulau Bintan memiliki tiga kondisi hidrogeologi, yaitu: (1) daerah air tanah langka; (2) daerah akuifer produktivitas rendah setempat berarti; dan (3) daerah akuifer setempat dengan produktifitas sedang. Daerah air tanah langka pada umumnya terdapat di tengah-tengah Pulau Bintan. Hal ini menjadi menarik karena granit yang timbul hanya di pesisir utara dan timur. Berdasarkan penampang geolistrik menunjukkan batuan granit berada di bawah batu lempung atau batu pasir. Daerah ini menjadi langka karena granit daerah tersebut lebih ke permukaan jika dibandingkan dengan daerah yang lainnya. Struktur yang terjadi di daerah tersebut hanya memperdalam lapisan air tanah sampai kedalaman sepuluh meter. Daerah Akuifer produktivitas rendah setempat berarti, daerah tersebut hampir mendominasi (70\%) Pulau Bintan, hal ini menunjukkan di Pulau Bintan tidak mempunyai lapisan akuifer dalam, sehingga air tanah hanya berada pada lapisan yang tidak terlalu dalam (permukaan). Hal ini dapat ditunjukkan hampir di selurah pulau ketersediaan air berada pada kedalaman enam sampai sepuluh meter. Daerah akuifer setempat dengan produktifitas sedang, daerah ini terdapat di daerah teluk, hal ini terjadi karena daerah tersebut merupakan daerah pengendapan aluvial (pasiran). Kedalaman air tanah di daerah tersebut dapat mencapai 35 sampai 40 meter.

Berdasarkan hasil survei dan pengolahan data menggunakan tool MapInfo 9.1, elevasi dan distribusi tinggi muka air tanah di lokasi studi ditunjukkan pada Gambar 7. Menurut hasil penelitian Rusli \& Fauzielly (2016), muka air tanah di Pulau Bintan hanya berkisar antara 0,4 sampai $7 \mathrm{~m}$ dibawah permukaan tanah. Hasil data survei yang dilakukan pada September tahun 2018 menunjukkan bahwa tinggi muka air tanah di lokasi studi berkisar antara 0,5 hingga 12,85 m dibawah permukaan tanah (rata-rata 5,3 m). Data survei diperoleh berdasarkan atas conto sumur di seluruh Pulau Bintan yang terdistribusi pada ketinggian (elevasi) 0 hingga $41 \mathrm{~m}$ dpl. Muka air tanah paling tinggi berada di sisi barat pulau dan paling rendah umumnya di pesisir pantai, yaitu di Kecamatan Teluk Sebong, Kecamatan Teluk Bintan, dan Gunung Kijang. Nilai survei pada studi ini berbeda dari data Rusli \& Fauzielly (2016) disebabkan karena perbedaan musim ketika data diambil. 


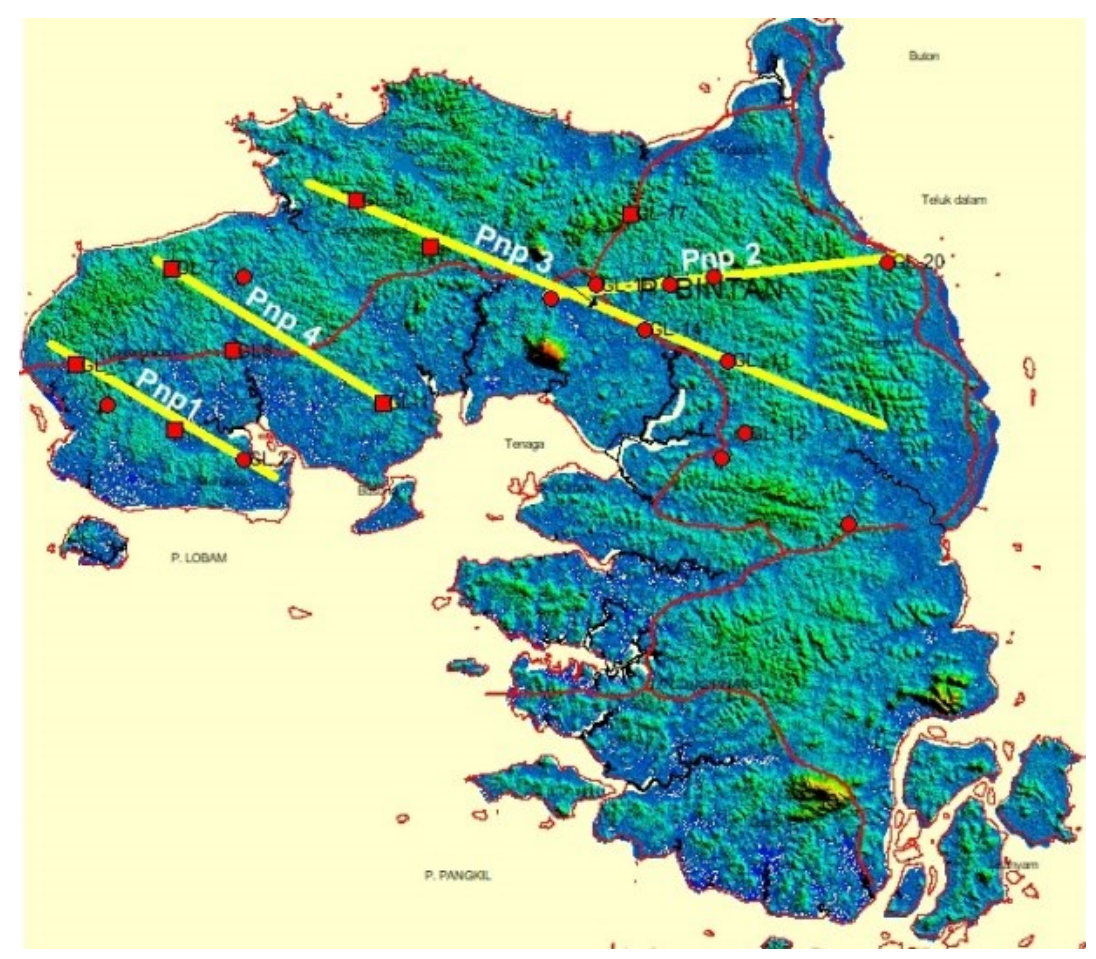

Gambar 4. Lintasan Geolistrik dengan Metode Schlumberger

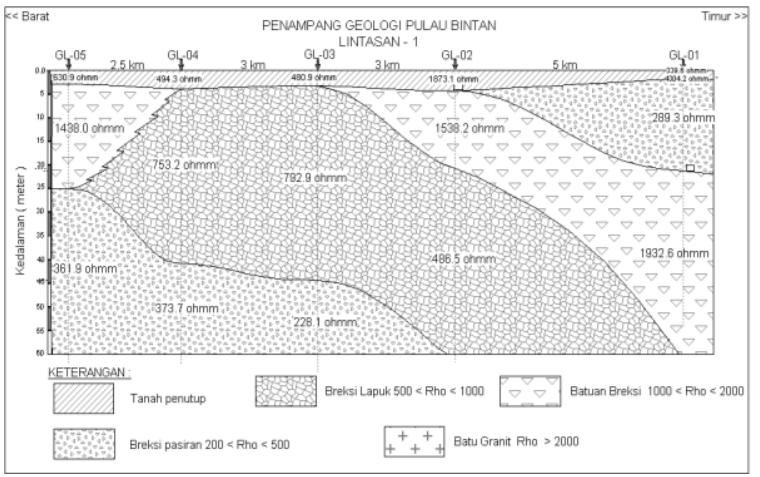

(a)

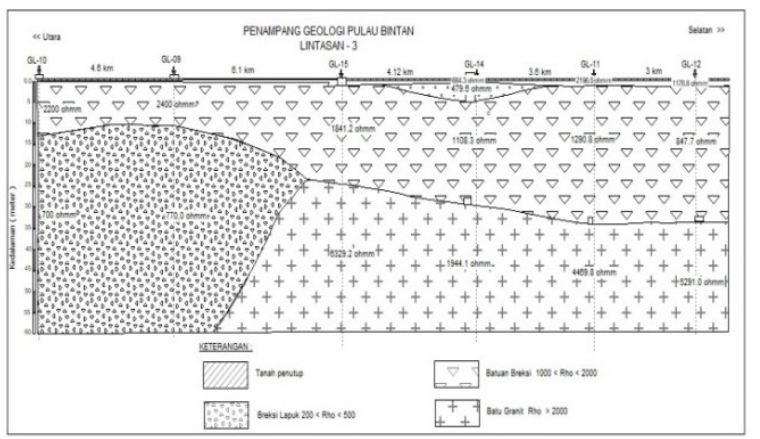

(c)

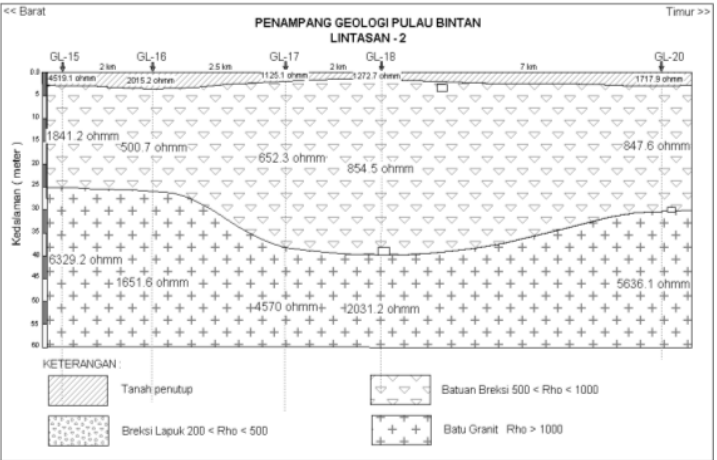

(b)

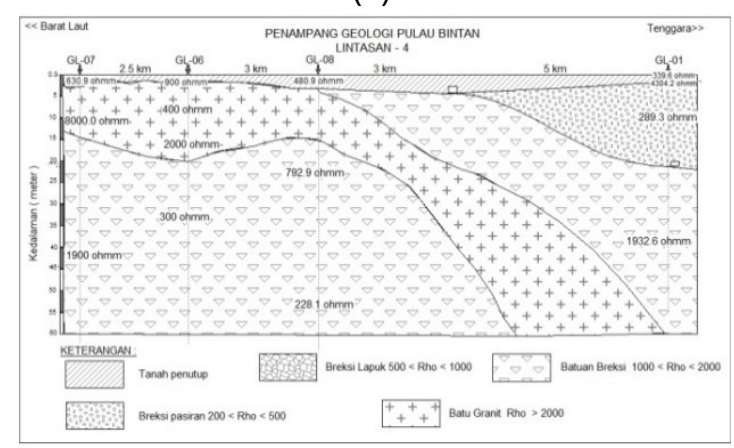

(d)

Gambar 5. Hasil Interpretasi Penampang Geologi Pulau Bintan dari empat Lintasan Uji Geolistrik: (a) Lintasan 1; (b) Lintasan 2; (c) Lintasan 3; dan (d) Lintasan 4 


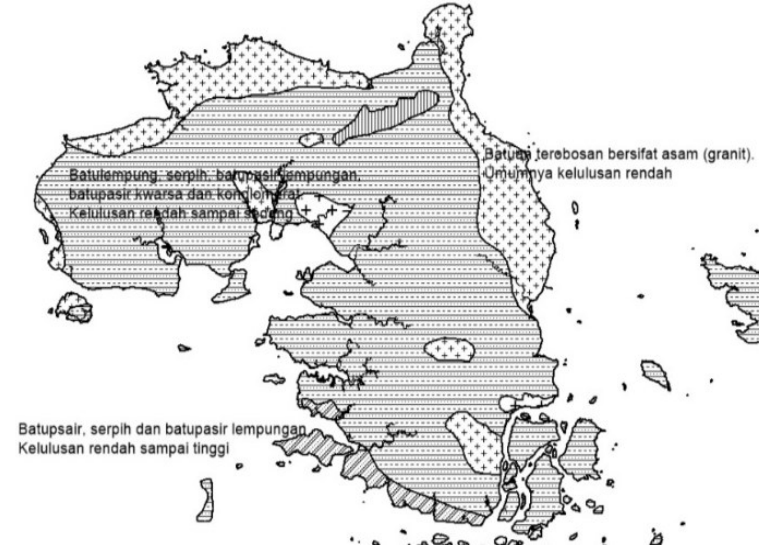

(a)

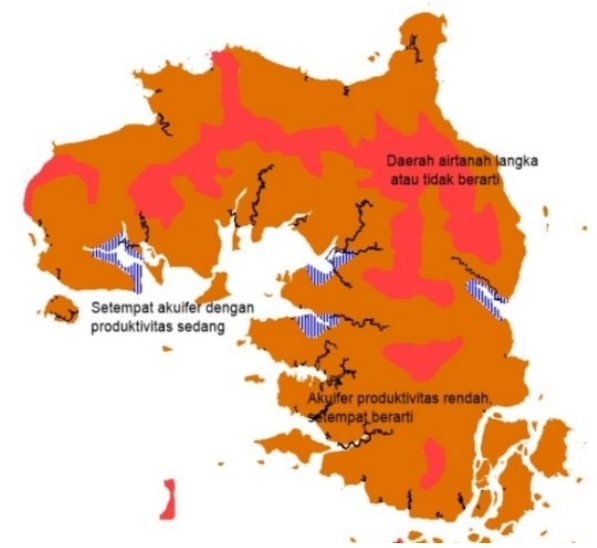

(b)

Sumber: Narulita et al., 2018

\section{Gambar 6. Sketsa Gambar (a) Peta Geologi dan (b) Peta Geohidrologi Pulau Bintan}

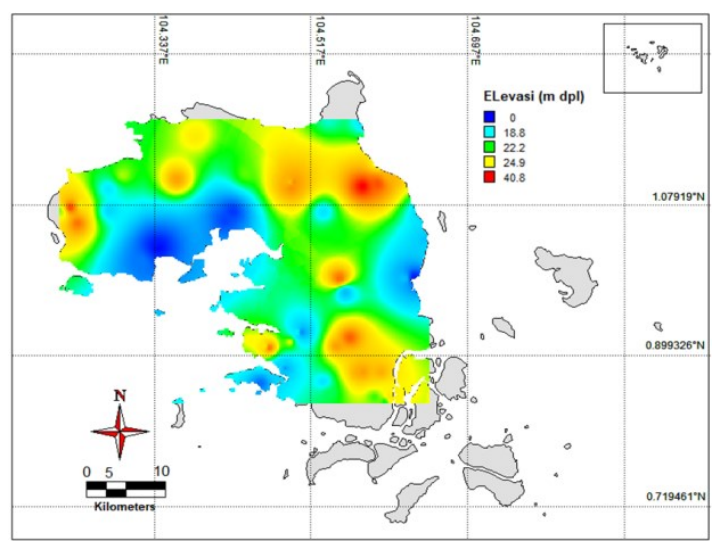

(a)

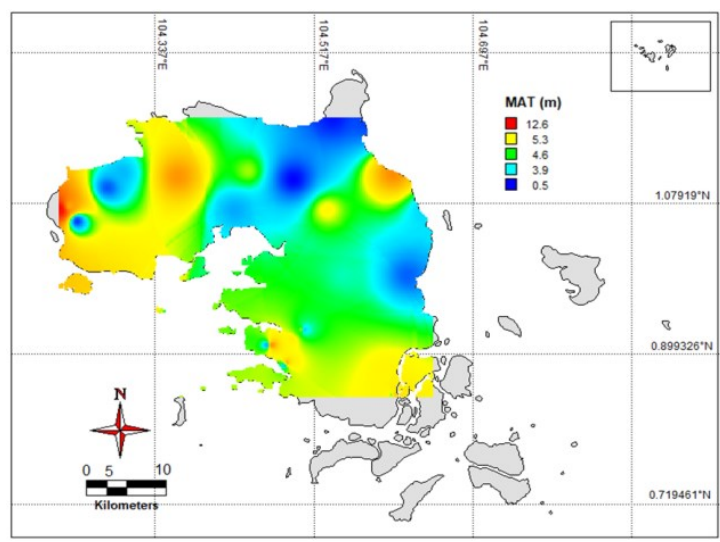

(b)

\section{Gambar 7. (a) Elevasi Permukaan dan (b) Tinggi Muka Air Tanah (MAT) dari Hasil Olah Data Survei Lokasi Pengambilan Sampel Air}

Oleh karena keterbatasan penyimpanan air tanah, maka usaha yang perlu dilakukan adalah membangun tampungan buatan (waduk). Keterbatasan sumber air baku ini telah disadari oleh Pemerintah Daerah setempat melalui pembangunan waduk sumber air baku. Gambar 8 adalah sketsa lokasi waduk eksisting dan rencana pengembangannya. Terdapat tujuh waduk eksisting di Pulau Bintan, dengan empat di antaranya saat ini menjadi sumber air baku PDAM Tirta Kepri yaitu Sei Pulai, Waduk Gesek, Kolong 6 (bekas tambang) dan Sei Jago. Sedangkan rencana pengembangan waduk adalah Dam Busung, Waduk Kawal, dan Waduk Galang Batang. Dam Busung adalah rencana pengembangan waduk terbesar untuk mengantispiasi peningkatan kebutuhan air baku di masa mendatang.

Kapasitas produksi dari empat sumber air baku PDAM Tirta Kepri sebesar 7.286.291 $\mathrm{m}^{3} /$ tahun dan $7.987 .877 \mathrm{~m}^{3} /$ tahun masing-masing di tahun 2016 dan tahun 2017. Namun produksi air baku baru tercapai $44 \%$ yaitu sebesar $3.201 .596 \mathrm{~m}^{3} / \operatorname{tahun}$ dan 3.521 .855 $\mathrm{m}^{3} /$ tahun masing-masing pada tahun 2016 dan 2017. Cakupan pelayanan PDAM Tirta Kepri baru mencapai $\pm 40 \%$, sehingga mayarakat yang tidak terlayani oleh PDAM Tirta 
Kepri masih sangat bergantung pada ketersediaan air tanah untuk memenuhi kebutuhan rumah tangganya. Sementara kebutuhan di sektor rumah tangga akan terus meningkat seiring dengan pertumbuhan jumlah penduduk.

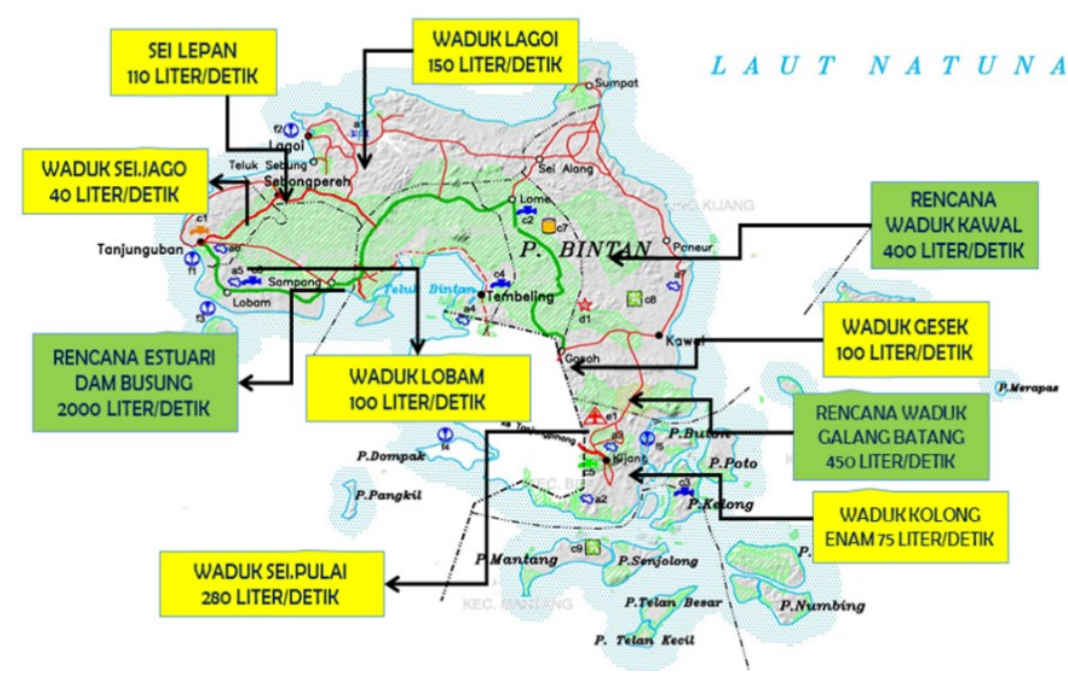

Sumber: Pemerintah Provinsi Kepulauan. Riau, 2018

\section{Gambar 8. Lokasi Sumber Air Baku Pulau Bintan (Eksisting dan Rencana Pengembangan)}

Gambar 9 menunjukkan peningkatan jumlah penduduk di Pulau Bintan dari tahun 2007 hingga tahun 2017. Pulau Bintan terdiri atas dua wilayah administratif yaitu Kota Tanjung Pinang dan Kabupaten Bintan. Kota Tanjung Pinang terdiri atas empat kecamatan dan Kabupaten Bintan terdiri atas sepuluh kecamatan. Berdasarkan data BPS (dapat dilihat pada Gambar 10) yang terbit tahun 2018, jumlah penduduk yang tinggal di Pulau Bintan pada akhir tahun 2017 sebanyak 363.370 jiwa dan terkonsentrasi di tiga wilayah, yaitu Kota Tanjung Pinang, Kecamatan Bintan Timur, dan Kecamatan Bintan Utara (Tanjung Uban).

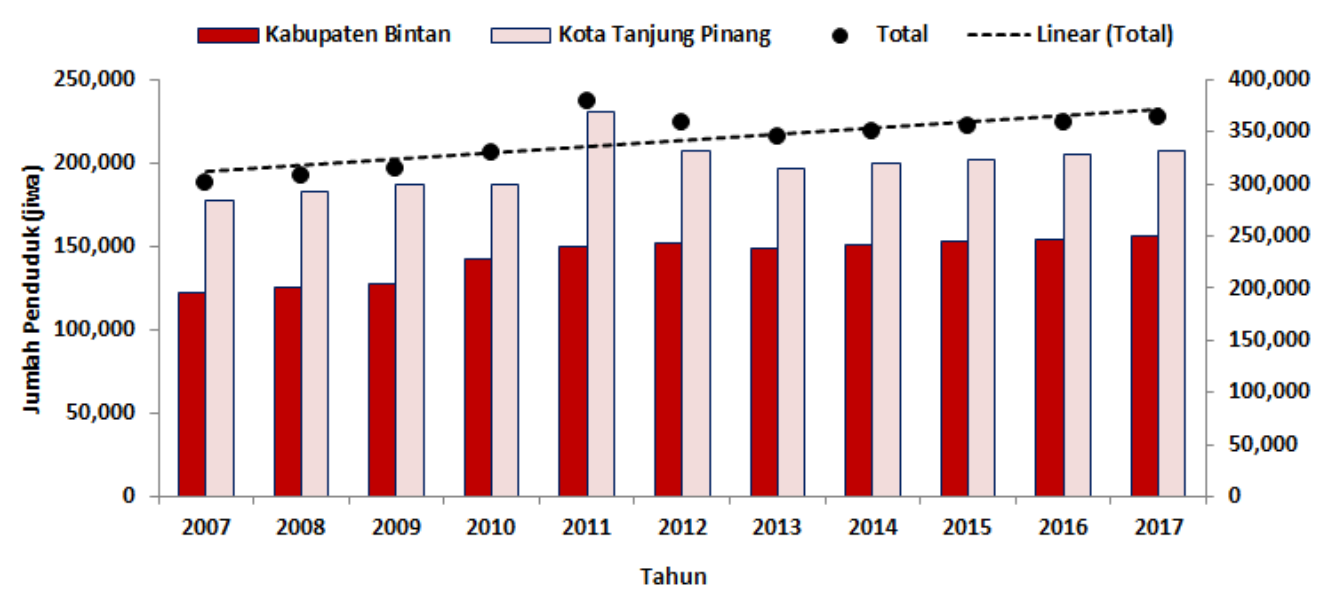

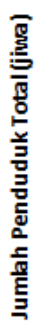

Gambar 9. Pertumbuhan Penduduk di Pulau Bintan 


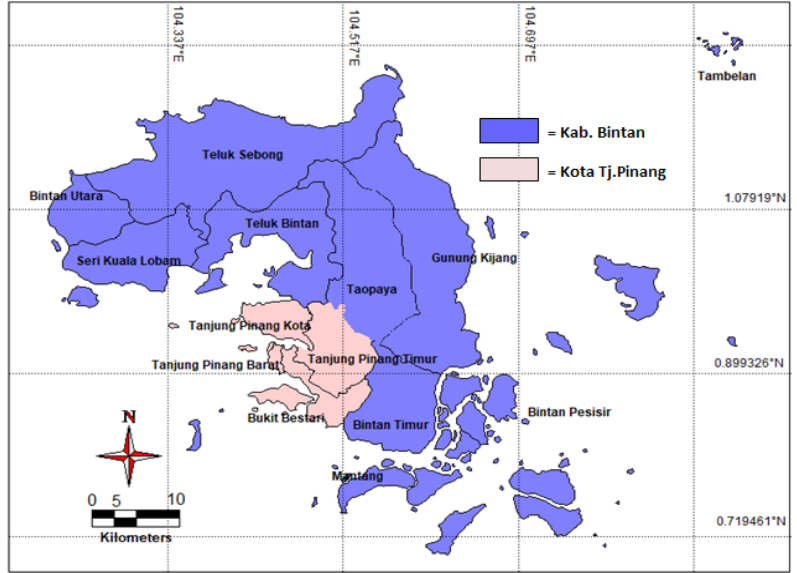

(a)

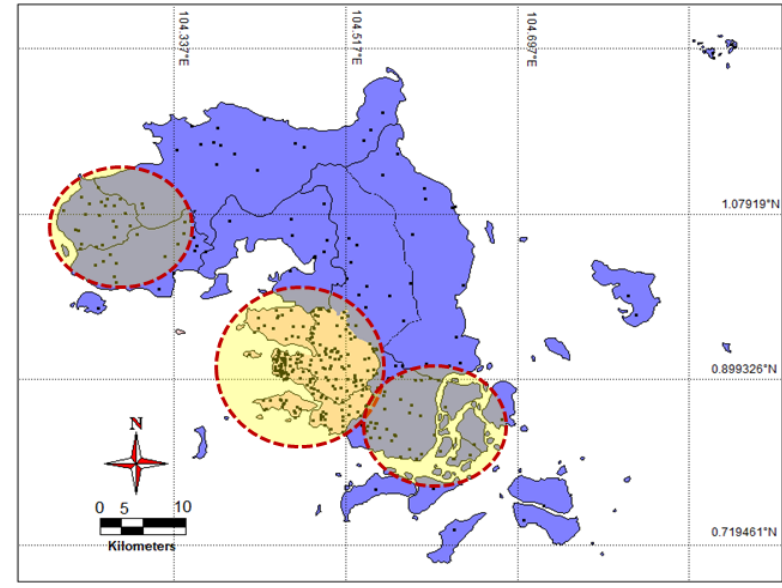

(b)

\section{Gambar 10. (a) Peta Pulau Bintan dan (b) Sebaran Peduduk di Setiap Kecamatan yang Berada di Pulau Bintan tahun 2017 (Satu dot matrik di peta mewakili 1000 jiwa penduduk)}

Dengan asumsi bahwa kebutuhan dasar perorang sebesar 60 L/orang/hari (Marganingrum et al., 2010), maka kebutuhan air baku air minum sebesar 7,869,086 $\mathrm{m}^{3} /$ tahun dan 7,957,803 $\mathrm{m}^{3} /$ tahun masing-masing untuk tahun 2016 dan 2017. Berdasarkan pendekatan jumlah penduduk ini, maka terjadi ketidakaseimbangan antara kebutuhan dan ketersediaan air baku (supply < demand), khususnya untuk kebutuhan sektor rumah tangga yang dipenuhi dari PDAM Tirta Kepri. Oleh karena itu, Pemerintah Daerah mengembangkan pembangunan waduk yaitu waduk Lagoi, Sei Lepan, dan Waduk Lobam dengan kapasitas masing-masing 150 L/detik, 110 L/detik dan 100 L/detik. Namun ketiga waduk tersebut lebih diperuntukkan untuk memenuhi kebutuhan di lokasi wisata yaitu di Kawasan Lagoi. Selain sektor wisata, kebutuhan air baku untuk rumah tangga juga mengalami persaingan untuk pemenuhan air baku di sektor industri dan jasa. Peningkatan kebutuhan air baku untuk sektor industri dan jasa merupakan dampak dari ditetapkannya kawasan Bintan menjadi Kawasan Perdagangan Bebas dan Pelabuhan Bebas (Free Trade Zone/FTZ) untuk jangka waktu 70 (PP Nomor 37 Tahun 2007). Kawasan Bintan yang dimaksud meliputi Industri Galang Batang, Kawasan Industri Maritim, dan Pulau Lobam di Kabupaten Bintan serta Kawasan Industri Senggarang dan Kawasan Industri Dompak Darat di wilayah Kota Tanjung Pinang.

Namun demikian, kebutuhan air baku untuk rumah tangga adalah kebutuhan utama yang harus dipenuhi terlebih dahulu dari kebutuhan lainnya. Oleh karena itu, syarat kuantitas dan kualitasnya harus tetap dijaga secara berkelanjutan. Keberadaan waduk penampung air hujan sangat penting untuk menjaga keberlanjutan kuantitas sumber air baku bagi masyarakat di Pulau Bintan. Waduk sebagai bangunan pengumpul air hujan atau sungai merupakan bentuk adaptasi suatu wilayah terhadap catchment area yang terbatas serta lapisan akuifer yang dangkal. Namun penentuan lokasi waduk perlu dilakukan secara cermat supaya waduk tersebut dapat berfungsi efektif dan efisien.

Salah satu poin penting dalam penentuan lokasi waduk adalah memahami arah aliran, baik aliran air permukaan maupun air tanah. Gambar 11 adalah pola aliran air permukaan dan pola aliran air tanah. Baik aliran permukaan maupun aliran air tanah di lokasi studi memiliki pola aliran yang sama, yaitu dari garis tengah pulau ke arah luar pulau. Sebagaimana kita ketahui, Pulau Bintan termasuk kategori pulau kecil dan sungainya relatif pendek sehingga dalam waktu singkat air hujan akan sampai di waduk-waduk penampungan atau ke laut. 
Berdasarkan pola aliran (Gambar 11) maka bisa dikatakan bahwa rencana pembangunan estuari DAM Busung sebagimana diperlihatkan pada Gambar 8, adalah tepat. Hampir 50\% aliran air (baik air permukaan maupun air hujan) akan mengalir ke rencana lokasi sehingga diperkirakan dapat menampung sejumlah air dengan kapasitas yang besar yaitu 2000 L/detik. Namun demikian perlu diperhatikan adalah kualitasnya. Membuat air yang tadinya payau menjadi air tawar tidaklah mudah. Hal ini memerlukan teknologi dan biaya yang tidak sedikit.

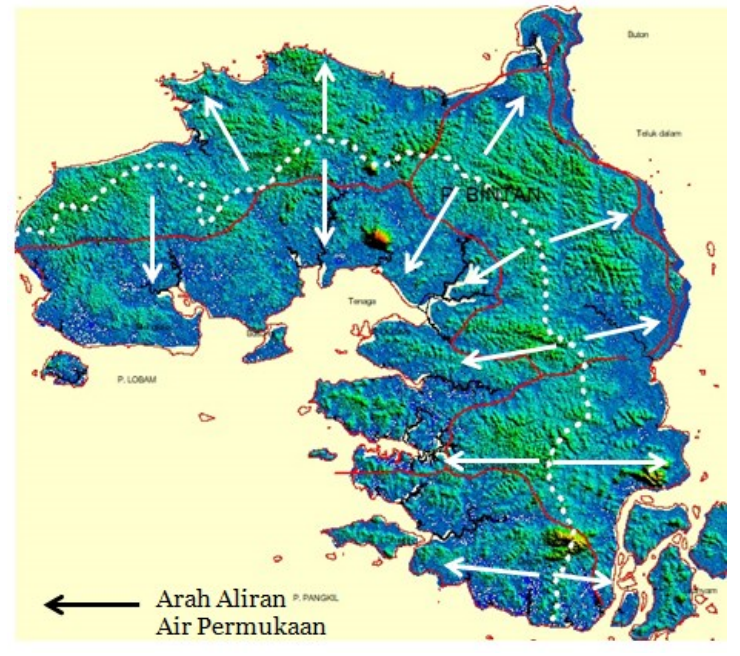

(a)

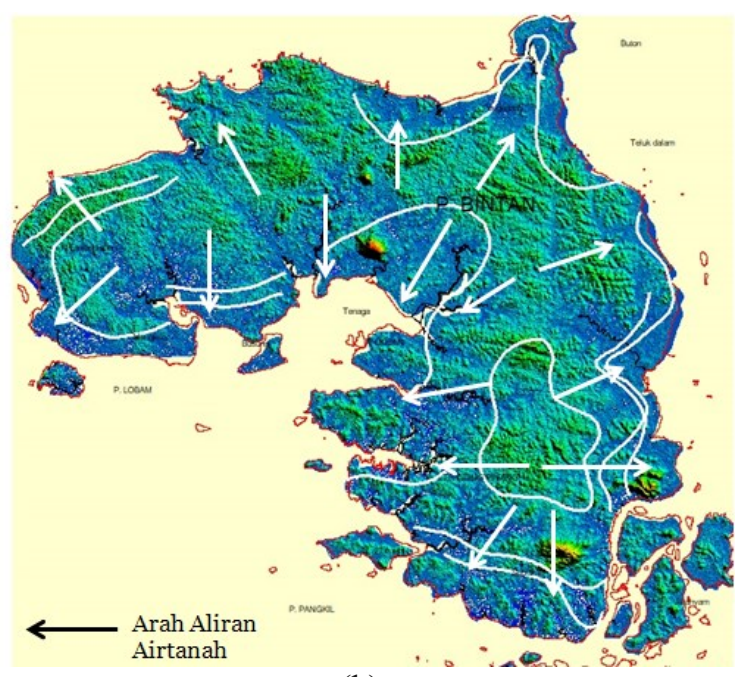

(b)

\section{Gambar 11. (a) Pola Aliran Air Permukaan dan (b) Aliran Air Tanah}

Dalam penyediaan air baku, khususnya untuk air minum, aspek kualitas memiliki kedudukan yang sama penting dengan aspek kuantitas. Dua faktor utama yang berpengaruh terhadap status kualitas sumber daya air di suatu wilayah, yaitu faktor alami (kondisi fisik alami wilayah dan lingkungan yang terdapat sumber air) dan faktor buatan (pengaruh aktivitas manusia).

Karakteristik kualitas sumber daya air dapat dipahami dengan melakukan pengambilan sampel air di beberapa titik yang tersebar di seluruh Pulau Bintan. Sebagaimana ditunjukkan pada Gambar 1 (lokasi pengambilan sampel air di Pulau Bintan), conto air terdiri atas sumur dan waduk/danau/tampungan air sebanyak 48 conto air. Sejumlah conto dianalisa sesuai standar air bersih karena menjadi sumber air utama bagi masyarakat Pulau Bintan (termasuk waduk yang menjadi sumber air baku PDAM Tirta Kepri). Sedangkan sisanya dianalisa insitu. Tabel 3 hingga Tabel 7 menyajikan data hasil analisis kualitas air sumur dan air permukaan conto air Pulau Bintan, baik in situ maupun pengukuran di laboratorium secara lengkap sesuai standar air bersih.

Berdasarkan hasil analisis in situ, semua conto air sumur (Tabel 3, Tabel 5) dan air permukaan (Tabel 4, Tabel 6, Tabel 7) menunjukkan kualitas yang baik, artinya dapat digunakan untuk memenuhi kebutuhan air baku rumah tangga. Hanya beberapa titik sumur yang memiliki $\mathrm{pH}$ dibawah baku mutu yang dipersyaratkan $(\mathrm{pH}<6)$, yaitu lokasi BP5A, BP15, BP16, BP20, BP22, BP35, BP39, dan BP40. Nilai pH yang rendah ada kaitannya dengan lokasi studi sebagai kawasan bekas tambang bauksit. Di kawasan bekas tambang akan terjadi penurunan $\mathrm{pH}$ tanah (Erfandi, 2017; Mensah, 2015). Tanah dengan $\mathrm{pH}$ rendah merupakan media kontak antara air hujan yang jatuh ke tanah dan air tanah (sumur). Dengan proses fisik kimawi (adveksi, dispersi dan retadasi) air hujan akan bereaksi dengan mineral-meneral di dalam tanah yang kemudian menyebabkan air sumur menjadi asam 


\section{Studi Kelayakan Sumber Daya Air Baku Pulau Bintan - Tinjauan Aspek Kuantitas dan Kualitas}

(Notodarmojo, 2005). Nilai DHL dan salinitas juga masih berada pada batas-batas klasifikasi air tawar. Berdasarkan nilai DHL dan salinitasnya, menunjukkan bahwa air tanah (sumur) di Pulau Bintan masih aman terhadap pengaruh intrusi air laut. Demikian halnya dengan air permukaan, parameter kualitas air hasil pemeriksaan insitu menunjukkan bahwa kualitas air permukaan di Pulau Bintan masih layak digunakan sebagai air baku air minum.

Tabel 3. Hasil Analisis Kualitas Air In Situ Untuk Conto Air Sumur

\begin{tabular}{|c|c|c|c|c|c|c|c|c|c|}
\hline No & Kode & Lokasi & ELEVASI & MAT & pH & DHL & Salinitas & $\mathbf{T}\left({ }^{\circ} \mathrm{C}\right)$ & Bau \\
\hline 1 & BP1 & Jl Sudimulyo dekat Perumahan Imigrasi & 34.05 & 8.75 & 6.65 & 104 & 0.00 & 27.8 & Tidak berbau \\
\hline 2 & BP2 & Kostan Bu Arbaiyah Jl, Batu Kucing No 1 & 25.82 & 2.35 & 7.11 & 220 & 0.00 & 27.2 & \\
\hline 3 & BP3 & Komplek TNI AL J1 Pattimura & 25.30 & 4.70 & 6.11 & 173 & 0.00 & 28.1 & Tidak berbau \\
\hline 4 & BP4 & Jl, DI Panjaitan Tukang Las & 24.75 & 5.65 & 6.80 & 40 & 0.00 & 27.8 & Tidak berbau \\
\hline 5 & BP5 & Perumahan Galang Permai & 23.85 & 7.45 & 6.20 & 81 & 0.00 & 27.9 & Tidak berbau \\
\hline 6 & BP5A & Warung penjual air di Galang Permai & 8.80 & 3.95 & & & & & \\
\hline 7 & $\mathrm{BP} 5 \mathrm{~B}$ & Rumah di dekat BP5A & 9.80 & 2.55 & 5.72 & 53 & 0.00 & 28.0 & \\
\hline 8 & BP6 & Batu Lapan Jl Cendrawasih & 18.80 & 2.20 & 6.70 & 136 & 0.00 & 27.6 & Tidak berbau \\
\hline 9 & BP6A & $\mathrm{Jl}$, Cendrawasih, Wonoyoso, Batu IX & 17.15 & 8.25 & 7.28 & 243 & 0.00 & 27.5 & \\
\hline 10 & $\mathrm{BP} 13$ & Wihara Darma Santi Tj Uban & 24.00 & 12.10 & 6.55 & 57 & 0.00 & 31.4 & Tidak berbau \\
\hline 11 & BP14 & $\mathrm{Jl}$, Indungsari, Tj Uban Timur & 33.60 & 1.15 & 6.20 & 18 & 0.00 & 28.0 & Tidak berbau \\
\hline 12 & BP15 & Kebun Karet Teluk Kebung & 17.50 & 1.70 & 5.86 & 18 & 0.00 & 26.8 & Tidak berbau \\
\hline 13 & BP16 & Warung di tenpat ngukur air hujan & 24.00 & 3.00 & 5.98 & 39 & 0.00 & 26.7 & Tidak berbau \\
\hline 14 & BP18 & Kimia Farma Kijang & 26.25 & 4.15 & 6.76 & 188 & 0.00 & 29.2 & Tidak berbau \\
\hline 15 & BP19 & Rumah Pensiunan Antam Kijang & 26.20 & 7.35 & 6.77 & 131 & 0.00 & 28.6 & Tidak berbau \\
\hline 16 & $\mathrm{BP} 20$ & Sumur deBintan Villla & 4.00 & 2.80 & 5.25 & 126 & 0.00 & 25.6 & Tidak berbau \\
\hline 17 & $\mathrm{BP} 21$ & Mesjid Nurul Huda Kangboi, Toapaya Utara & 16.95 & 5.45 & 6.76 & 32 & 0.00 & 26.5 & Tidak berbau \\
\hline 18 & $\mathrm{BP} 22$ & Kp, Like Km 47, Teluk Bintan & 26.90 & 0.50 & 5.54 & 15 & 0.00 & 26.0 & \\
\hline 19 & BP22A & Sumur Kering dekat BP22 & 33.60 & 8.35 & & & & & \\
\hline 20 & $\mathrm{BP} 23$ & Mesjid Nurul Huda Kangboi, Toapaya Utara & 16.95 & 5.45 & 6.39 & 24 & 0.00 & 26.5 & \\
\hline 21 & $\mathrm{BP} 24$ & Ds, Toapaya, Kec, Toapaya & 33.90 & 4.10 & 6.52 & 20 & 0.00 & 26.8 & \\
\hline 22 & $\mathrm{BP} 25$ & Kawal, Gn Kijang & 14.60 & 1.80 & 6.94 & 151 & 0.00 & 26.8 & \\
\hline 23 & $\mathrm{BP} 26$ & Kp, Mengkurus, Ds, Teluk Bakau, Gn, Kijang & 15.65 & 3.40 & 8.02 & 491 & 0.02 & 29.1 & \\
\hline 24 & $\mathrm{BP} 27$ & Kp, Kampe, Ds, Mangrapat, Kec, Gn,Kijang & 17.30 & 1.35 & 8.12 & 759 & 0.03 & 28.6 & \\
\hline 25 & $\mathrm{BP} 28$ & Ds, Pengudang, Teluk Sebong & 19.40 & 0.75 & 7.38 & 63 & 0.00 & 27.8 & \\
\hline 26 & $\mathrm{BP} 29$ & Ds, Sri Bintan, Kec, Teluk Sebong & 24.96 & 8.29 & 7.93 & 68 & 0.00 & 26.6 & \\
\hline 27 & BP29A & Warung dekat BP 29 & 21.40 & 1.78 & 6.38 & 31 & 0.00 & 27.3 & \\
\hline 28 & $\mathrm{BP} 30$ & Simpang Lagoi, Teluk Sebong & 30.55 & 8.30 & 6.63 & 68 & 0.00 & 27.1 & \\
\hline 29 & BP34 & Ds, Malang Rapat, Gn, Kijang & 29.50 & 8.50 & 7.43 & 74 & 0.00 & 27.6 & \\
\hline 30 & $\mathrm{BP} 35$ & BP Kijang, Jl Nusantara Km 23 Kijang & 29.85 & 5.55 & 5.64 & 18 & 0.00 & 26.6 & \\
\hline 31 & $\mathrm{BP} 36$ & BP Kuala Simpang, Kuala Simpang & & & 7.05 & 22 & 0.00 & 30.3 & \\
\hline 32 & BP38 & Yayasan Towdah & 20.30 & 12.85 & & & & & \\
\hline 33 & BP39 & BP Wiyono, Jl Permaisuri, Tj Uban & 26.25 & 12.65 & 5.94 & 69 & 0.00 & 29.4 & \\
\hline 34 & $\mathrm{BP} 40$ & BP I 2, Bpk Suwardi Perum Bintan Indah 2 & 36.45 & 7.80 & 5.74 & 111 & 0.00 & 30.0 & \\
\hline 35 & BP42 & BP Hansong & 21.00 & & & & & & \\
\hline 36 & BP43 & BP Kab Bintan & 32.00 & & & & & & \\
\hline 37 & BP44 & BP Kangkung & 17.00 & & & & & & \\
\hline 38 & BP45 & BP Karet Luas & 22.00 & & & & & & \\
\hline 39 & $\mathrm{BP} 46$ & BP Kuala Simpang2 & 2.00 & & & & & & \\
\hline 40 & BP47 & BP Museum Bahari & 16.00 & & & & & & \\
\hline 41 & BP48 & BP Sei Jeram & 16.00 & & & & & & \\
\hline 42 & BP49 & BP Tambak Jembatan Uban & 5.00 & & & & & & \\
\hline 43 & BP50 & BP Kampung Nelayan & 2.00 & & & & & & \\
\hline 44 & BP51 & BP Sawit & 36.00 & & & & & & \\
\hline 45 & BP52 & BP Sawit2 & 41.00 & & & & & & \\
\hline 46 & BP54 & BP Trikora & 25.00 & & & & & & \\
\hline 47 & BP55 & AMDK Bestari & 30.00 & & & & & & \\
\hline 48 & BP56 & AMDK Sanford & 31.00 & & & & & & \\
\hline \multicolumn{5}{|c|}{ BAKU MUTU PP 82/2001 untuk Kelas I } & $6-9$ & & & $\begin{array}{l}\text { Deviasi } 3 \\
\left({ }^{\circ} \mathrm{C}\right)\end{array}$ & \\
\hline
\end{tabular}

Keterangan: \#Tabel kosong = tidak dilakukan pengukuran

Namun berdasarkan hasil analisis laboratorium, ada tiga paramater yang melebihi baku mutu, yaitu besi dan COD, baik untuk air sumur maupun air permukaan (Tabel 4 dan Tabel 5). Air adalah zat pelarut universal sehingga kualitas air akan sangat dipengaruhi oleh kondisi lingkungan di sekitarnya, termasuk faktor geologi. Lamanya waktu kontak antara batuan dengan air juga mempengaruhi kandungan unsur-unsur dalam air. Makin lama air kontak dengan batuan, maka makin banyak peluang terjadinya pelarutan garam-garam dan mineral yang ada dalam batuan. Kondisi ini sulit terjadi di Pulau Bintan mengingat 
catchment area yang terbatas dan sungainya pendek. Oleh karena itu, secara umum (kecuali kandungan besi) kandungan unsur-unsur dalam conto air yang dianalisa relatif kecil.

Tabel 4. Hasil Analisis Kualitas Air In Situ Untuk Conto Air Permukaan/Waduk/Embung/Danau

\begin{tabular}{|c|c|c|c|c|c|c|c|c|}
\hline No & Kode & Lokasi & $\begin{array}{l}\text { ELEVAS } \\
\text { I }\end{array}$ & pH & DHL & $\begin{array}{l}\text { Salinit } \\
\text { as }\end{array}$ & $\mathbf{T}\left({ }^{\circ} \mathrm{C}\right)$ & Bau \\
\hline 1 & BP6B & Air Permukaan dekat BP6 & 7.00 & 7.66 & 213 & 1.28 & 31.2 & \\
\hline 2 & BP7 & Intake Waduk Sei Pulai & 31.00 & 7.58 & 12 & 0.00 & 29.0 & Tidak berbau \\
\hline 3 & BP8 & Tali Air Waduk Sei Pulai & 35.00 & 6.95 & 18 & 0.00 & 27.5 & Tidak berbau \\
\hline 4 & BP9 & Waduk Gesek & 14.00 & 6.40 & 19 & 0.00 & 26.2 & Tidak berbau \\
\hline 5 & BP10 & Embung Dompak & 8.25 & 7.51 & 40 & 0.00 & 28.7 & Tidak berbau \\
\hline 6 & BP11 & Waduk Kolong 6 & 22.70 & 8.40 & 23 & 0.00 & 29.8 & Tidak berbau \\
\hline 7 & BP12 & Waduk Sei Jago & 26.00 & 8.05 & 13 & 0.00 & 30.9 & Tidak berbau \\
\hline 8 & BP17 & Danau Depan Masjid Kijang & 22.00 & 7.03 & 62 & 0.00 & 29.2 & Tidak berbau \\
\hline 9 & BP31 & Waduk Lagoi & 26.00 & 7.25 & 9 & 0.00 & 30.1 & \\
\hline 10 & BP32 & $\begin{array}{l}\text { Danau Bekas Tambang Toren Sembunyi, Teluk } \\
\text { Bakau, Gn, Kijang }\end{array}$ & 17.00 & 7.39 & 53 & 0.00 & 30.8 & \\
\hline 11 & BP33 & $\begin{array}{l}\text { Danau Hijau Anak Berenang, Teluk Bakau, Gn, } \\
\text { Kijang }\end{array}$ & 16.00 & 6.33 & 28 & 0.00 & 30.7 & \\
\hline 12 & BP37 & Danau Biru & 9.00 & 6.22 & 14 & 0.00 & 29.8 & \\
\hline \multirow[t]{2}{*}{13} & BP53 & BP Torn Sembunyi & 10.00 & & & & & \\
\hline & & BAKU MUTU PP 82/2001 untuk Kelas I & & $6-9$ & - & - & & \\
\hline
\end{tabular}

Tingginya kandungan besi dalam air sangat logis karena sebagian besar mineral yang ditemukan dalam tanah dan batuan di Pulau Bintan mengandung unsur besi, yaitu mineral - mineral magnetit $\left(\mathrm{Fe}_{3} \mathrm{O}_{4}\right)$, hematit $\left(\mathrm{Fe}_{2} \mathrm{O}_{3}\right)$, kasiterit $\left(\mathrm{SnO}_{2}\right)$ plagioklas, feldspar, biotit $\left(\mathrm{K}(\mathrm{Mg}, \mathrm{Fe}) 3 \mathrm{AlSi}_{3} \mathrm{O}_{10}(\mathrm{FeOH})_{2}\right)$ yang merupakan hasil pelapukan dari batuan andesit dan granit penyusun litologi utama di Pulau Bintan. Hal ini diperkuat dengan analisis menggunakan diagram Gibb’s (Ravikumar, Somashekar, \& Prakash, 2015). Dari diagram Gibb's (Gambar 12) diketahui bahwa kualitas air (baik air sumur maupun air permukaan) lebih dikendalikan oleh proses pelapukan batuan yang ada di lokasi studi. Untuk air permukaan, terlihat juga adanya pengaruh dari air hujan atau atmosferik (Gambar 12.b).

Salah satu parameter yang berpengaruh dalam proses pelarutan batuan adalah tingkat keasaman $(\mathrm{pH})$ air. Meskipun ada 8 titik air sumur dengan $\mathrm{pH}<6$, namun secara umum dapat dikatakan bahwa $\mathrm{pH}$ conto air yang diambil memiliki nilai $\mathrm{pH}$ sesuai baku mutu (6 - 9). Hasil survei dan analisis conto air hujan di Pulau Bintan ditunjukkan pada Tabel 7. Nilai $\mathrm{pH}$ air sumur maupun air permukaan dapat berhubungan langsung dengan pH air hujan (Tabel 8) melalui proses infiltrasi dan perkolasi serta reaksi fisik, kimiawi, dan biologis yang terjadi ketika air hujan mengalir melalui pori-pori tanah dan celah batuan menuju zona air tanah atau mengalir sebagai limpasan air permukaan.

Analisis kualitas air sumur dan air permukaan menggunakan metode WQI ditampilkan pada Gambar 13. Secara umum air sumur di lokasi studi adalah tercemar ringan (WQI $=0,59)$, sedangkan air permukaan tercemar sedang $(\mathrm{WQI}=1,01)$. Sesuai dengan standar baku mutu yang digunakan, yaitu PP Nomor 82 Tahun 2001, parameter yang digunakan dalam perhitungan WQI ditunjukkan pada diagram radar (Gambar 14). 


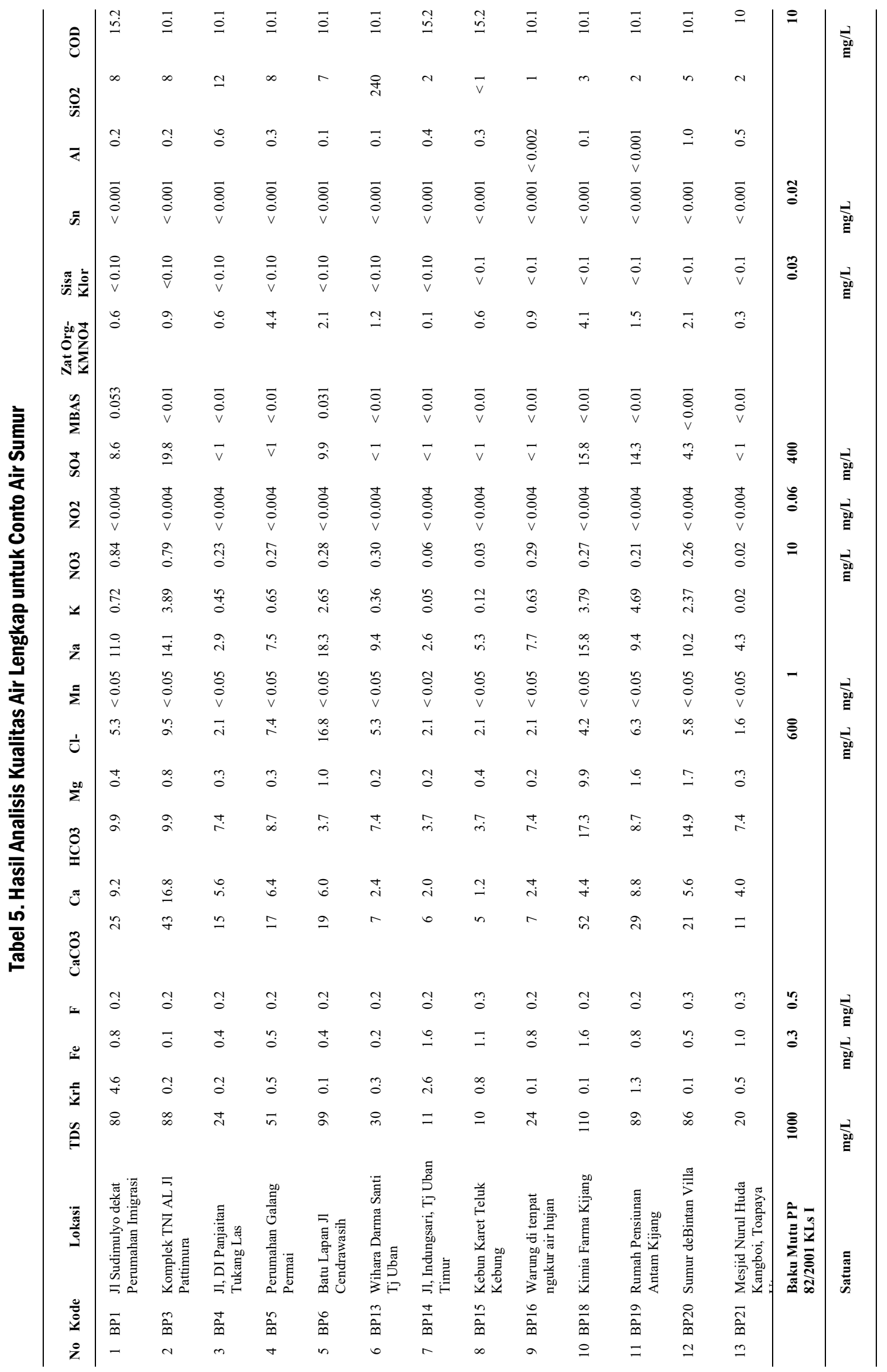




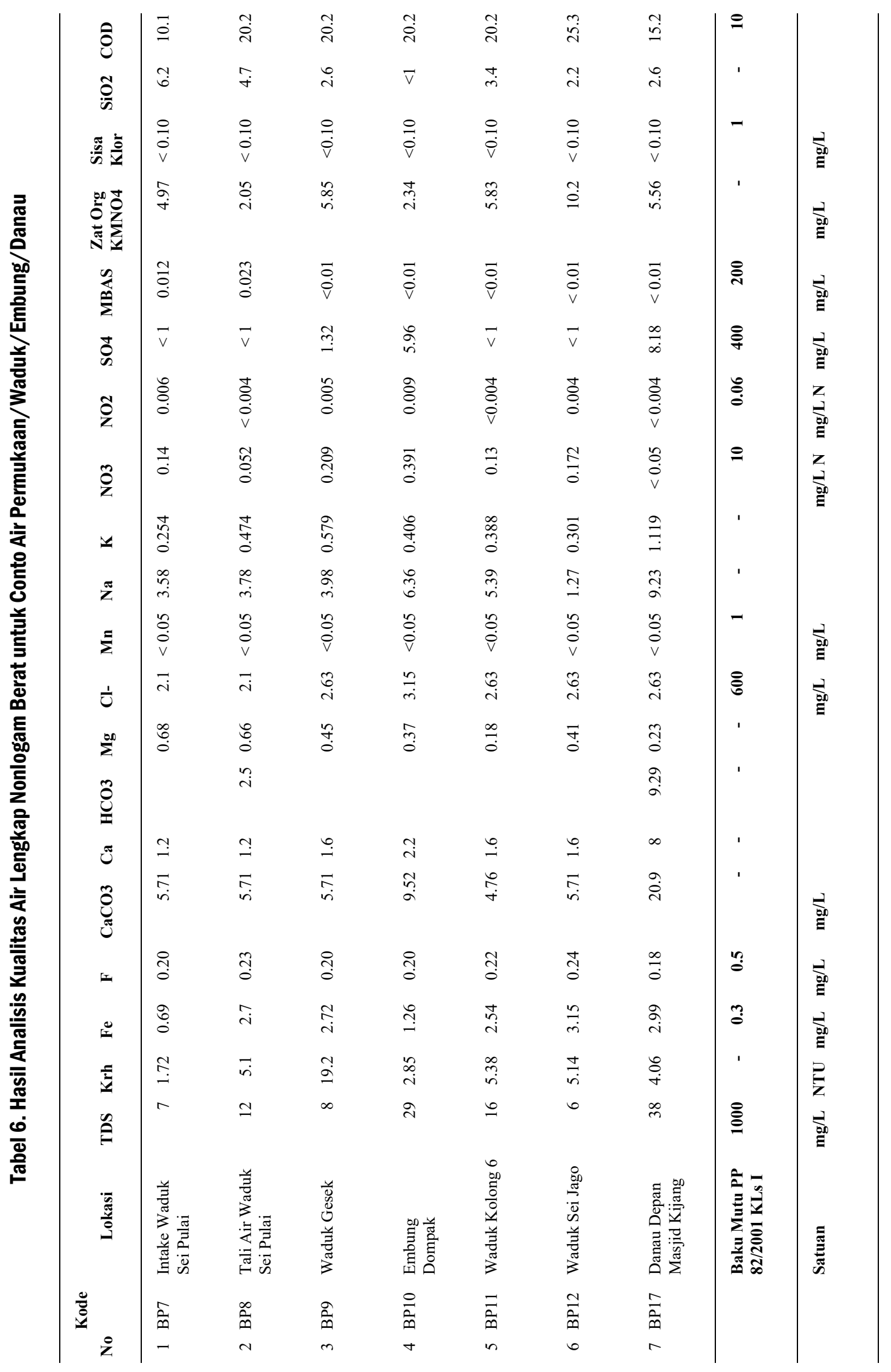


Tabel 7. Hasil Analisis Logam Berat Untuk Conto Air Permukaan/Waduk/Embung/Danau

\begin{tabular}{|c|c|c|c|c|c|c|c|c|c|c|c|}
\hline No & Kode & Lokasi & Hg & As & Cd & $\mathrm{Cr}$ & Se & Zn & $\mathbf{P b}$ & Sn & Al \\
\hline 1 & BP7 & Intake Waduk Sei Pulai & $<0.05$ & - & $<0.001$ & $<0.001$ & $<0.001$ & 0.0031 & $<0.001$ & $<0.001$ & $<0.001$ \\
\hline 2 & BP8 & Tali Air Waduk Sei Pulai & & & & & & & & $<0.001$ & 0.143 \\
\hline 3 & BP9 & Waduk Gesek & $<0.05$ & - & $<0.001$ & $<0.001$ & $<0.001$ & $<0.0001$ & $<0.001$ & $<0.001$ & 0.449 \\
\hline 4 & BP10 & Embung Dompak & $<0.05$ & - & $<0.001$ & $<0.001$ & $<0.001$ & 0.0384 & $<0.001$ & $<0.001$ & $<0.001$ \\
\hline 5 & BP11 & Waduk Kolong 6 & $<0.05$ & - & $<0.001$ & $<0.001$ & $<0.001$ & 0.0111 & $<0.001$ & $<0.001$ & 0.293 \\
\hline 6 & BP12 & Waduk Sei Jago & $<0.05$ & - & $<0.001$ & $<0.001$ & $<0.001$ & $<0.0001$ & $<0.001$ & $<0.001$ & 0.53 \\
\hline \multirow[t]{3}{*}{7} & BP17 & Danau Depan Masjid Kijang & & & & & & & & $<0.001$ & 0.612 \\
\hline & & Baku Mutu PP 82/2001 KLs I & 0.001 & 0.05 & 0.01 & 0.05 & 0.01 & 0.05 & 0.03 & 0.01 & - \\
\hline & & (Satuan) & $\mathrm{mg} / \mathrm{L}$ & $\mathbf{m g} / \mathbf{L}$ & $\mathbf{m g} / \mathbf{L}$ & $\mathbf{m g} / \mathbf{L}$ & $\mathbf{m g} / \mathbf{L}$ & $\mathbf{m g} / \mathbf{L}$ & $\mathbf{m g} / \mathbf{L}$ & $\mathbf{m g} / \mathbf{L}$ & $\mathbf{m g} / \mathbf{L}$ \\
\hline
\end{tabular}
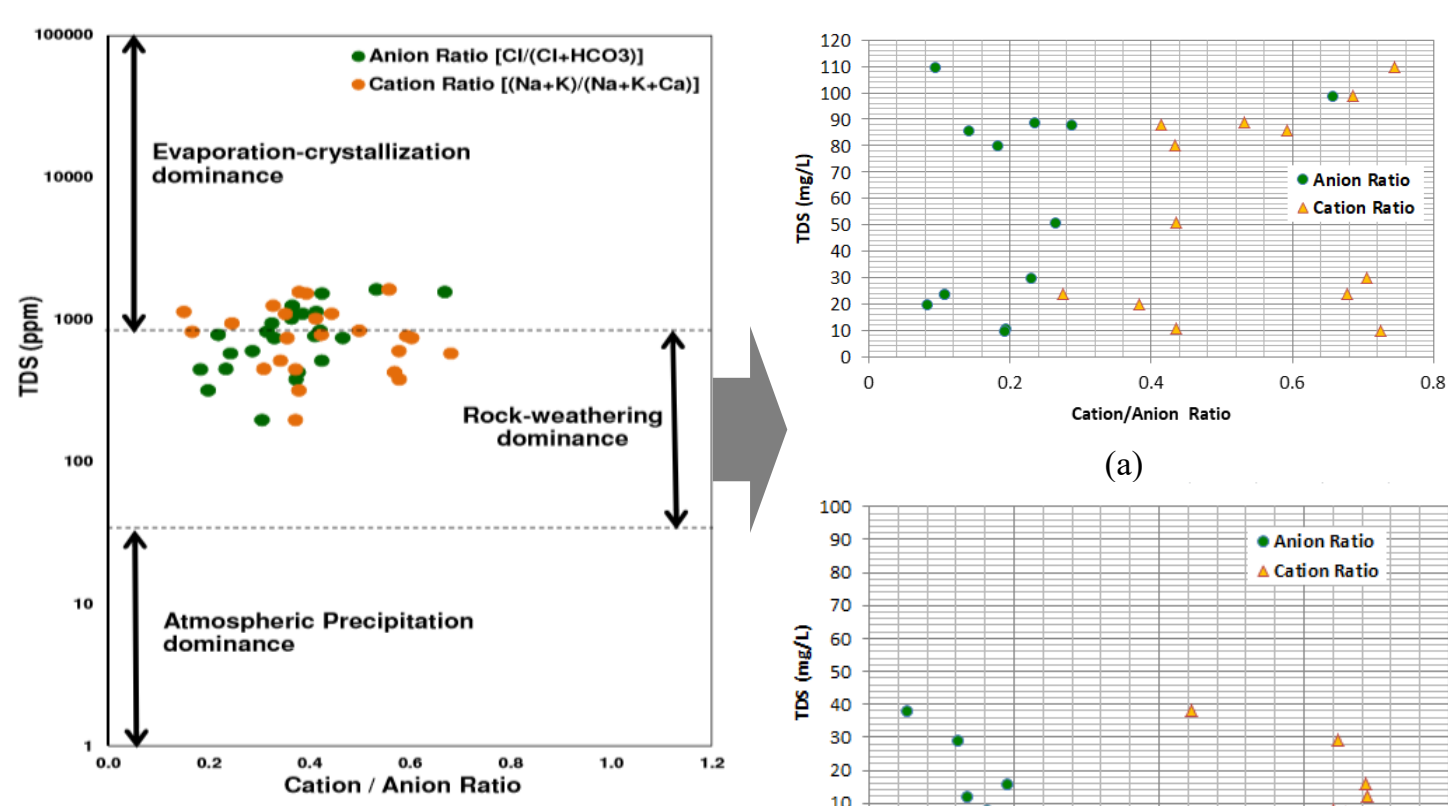

(a)

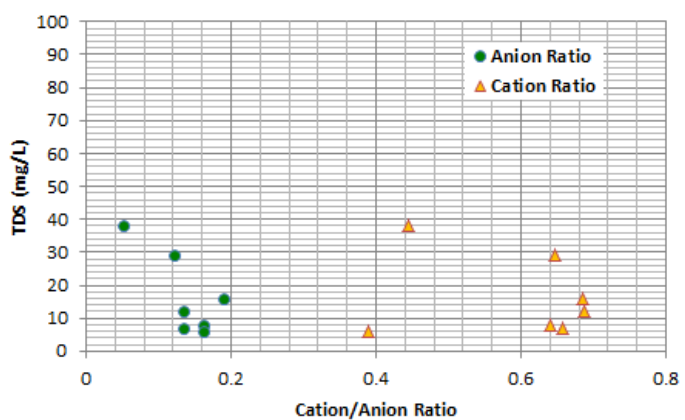

(b)

\section{Gambar 12. Conto Air Pulau Bintan Berdasarkan Analisis Diagram Gibb's: (a) Air Sumur dan (b) Air Permukaan}

Parameter besi yang memberikan nilai perbedaan signifikan antara air sumur dan air permukaan. Kandungan besi di air permukaan lebih tinggi daripada di air sumur. Hal ini terkait dengan curah hujan yang tinggi mengikis permukaan tanah yang mengandung besi dan membawanya ke storage-storage (tampungan atau waduk) melaui proses aliran permukaan (direct runoff). Ini diperkuat dengan hasil analisis Digram Gibb's bahwa terdapat pengaruh atmosferik terhadap kelarutan anion dan kation pada air permukaan.

Tabel 8. Hasil Analisis In Situ Conto Air Hujan di Lokasi Studi pada Dua Titik

\begin{tabular}{llcccc}
\hline Kode & \multicolumn{1}{c}{ Lokasi } & pH & DHL & Salinitas & T \\
\hline BP16A & Air Hujan dekat warung BP16A & 7.33 & 25 & 0.00 & 25.8 \\
BP41 & Air Hujan Villa deBintan & 6.94 & 32 & 0.00 & 23.8 \\
\hline
\end{tabular}




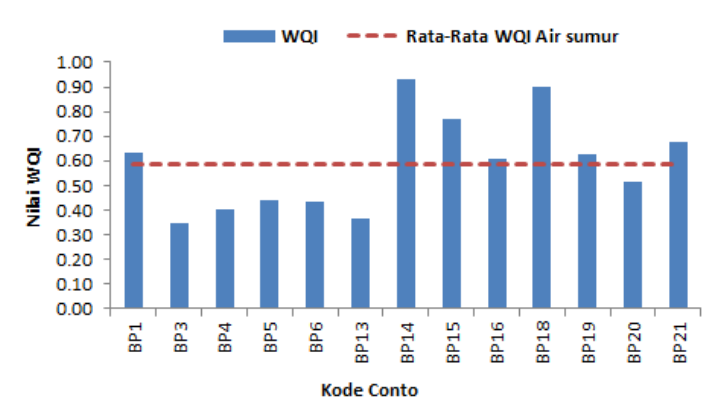

(a)

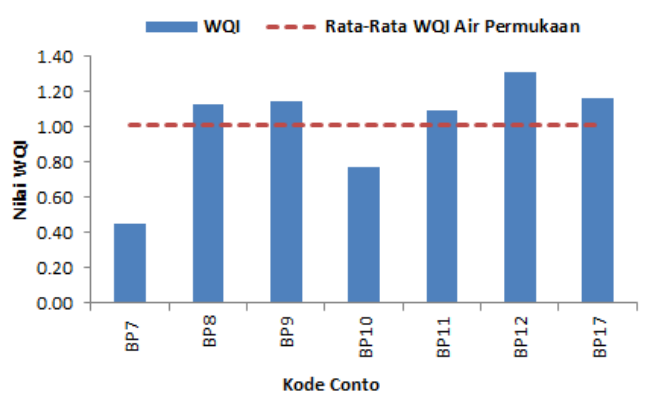

(b)

\section{Gambar 13. Hasil Analisis Nilai Water Quality Index (WQI) Conto (a) Air Sumur dan (b) Air Permukaan Pulau Bintan}

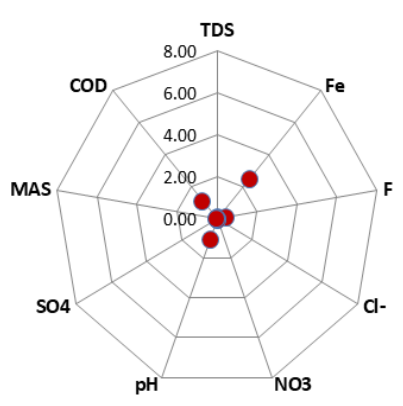

(a)

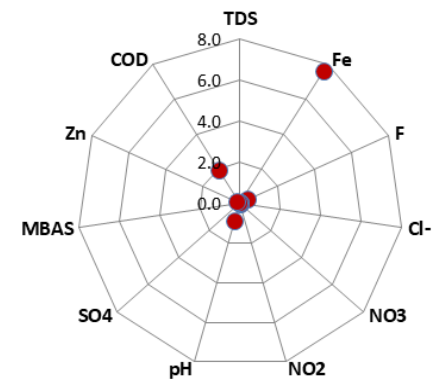

(b)

\section{Gambar 14. Diagram Radar Nilai WQI Berdasarkan Parameter (a) Air Sumur dan (b) Air Permukaan}

Berdasarkan informasi yang diperoleh dari survei lapangan dan diskusi dengan pemangku kepentingan setempat, Pulau Bintan akan dijadikan sebagai salah satu Kawasan Ekonomi Khusus (KEK) selain Batam dan Karimum. Salah satu persyaratan pembentukan KEK adalah kawasan tersebut harus terkait dengan kawasan pengembangan lainnya yang ditujukan oleh tersedianya dukungan infrastruktur dan fasilitas pendukung. Salah satu fasilitas pendukung adalah pasokan air minum sebesar 1 liter/detik/hektar (Adisasmita, 2013).

Penetapan Kawasan Bintan sebagai KEK juga memberikan dampak terhadap perkembangan kota di lokasi studi yang akan berkontribusi terhadap penurunan $\mathrm{pH}$ hujan melalui emisi udara dari kegiatan industri dan jasa serta transportasi. Hujan dengan keasaman tinggi akan berpengaruh langsung terhadap pelapukan batuan dan lebih lanjut akan meningkatkan kadar besi terlarut dalam air, baik air tanah maupun air permukaan. Meskipun dalam kadar tertentu tidak bersifat toksik bagi kesehatan manusia, namun kandungan besi yang tinggi akan menyebabkan air berwarna merah, membuat peralatan berkarat, serta menghambat fiksasi unsur lainnya (Effendi, 2003).

\section{Kesimpulan}

Berdasarkan pertimbangan aspek kuantitas dan kualitasnya, sumber air baku di Pulau Bintan belum mampu memenuhi kebutuhan yang terus meningkat. Hal ini disebabkan karena secara fisik alaminya Pulau Bintan memiliki keterbatasan. Keterbatasan tersebut 


\section{Studi Kelayakan Sumber Daya Air Baku Pulau Bintan - Tinjauan Aspek Kuantitas dan Kualitas}

dikaitkan dengan faktor kondisi geologi dan tanah di lokasi penelitian yang tidak dapat menyerap dan menyimpan air hujan secara maksimal, meskipun curah hujannya cukup tinggi. Keterbatasan dari aspek kuantitas menjadi lebih buruk dengan penurunan kualitas air karena media tanah di lokasi penelitian mengandung mineral besi yang cukup tinggi.

Hasil penelitian ini dapat memberikan landasan khususnya dalam pengambilan kebijakan pengelolaan sumber daya air di lokasi penelitian serta penerapan teknologi yang tepat guna untuk menjamin keberlanjutan sumber daya air di lokasi penelitian. Teknologi penangkapan air hujan serta penurunan kadar besi dapat digunakan sebagai rekomendasi untuk penyediaan kebutuhan air bersih.

\section{Ucapan Terima Kasih}

Penulis mengucapkan terima kasih kepada Coremap CTI LIPI yang telah membiayai kegiatan penelitian ini dalam program kegiatan Demand Driven Research Grant (DDRG) Tahun Anggaran 2018. Penulis juga mengucapkan terima kasih kepada semua anggota tim yang tergabung dalam kegiatan ini. Tidak lupa penulis mengucapkan terima kasih kepada BAPPEDA Provinsi Kepulauan Riau, Dinas Pekerjaan Umum, Penataan Ruang, dan Pertanahan Provinsi Kepulauan Riau, Dinas Energi dan Sumber Daya Mineral Provinsi Kepulauan Riau, Dinas Kesehatan Provinsi Kepulauan Riau, Dinas Lingkungan Hidup dan Kehutanan Provinsi Kepulauan Riau, PDAM Tirta Kepri Provinsi Kepulauan Riau, serta beberapa dinas lainnya yang terkait di tingkat Kabupaten Bintan dan Kota Tanjungpinang, atas bantuan dan partisipasinya dalam pelaksanaan kegiatan penelitian ini.

\section{Daftar Pustaka}

Adisasmita, R. (2013). Pembangunan kawasan dan tata ruang. Yogyakarta: Graha Ilmu.

Apriadi, T., \& Ashari, I. H. (2018). Struktur komunitas fitoplankton pada kolong pengendapan limbah tailing bauksit di Senggarang, Tanjungpinang. Majalah Ilmiah Biologi Biosfera: A Scientific Journal, 35(3), 145152. doi:10.20884/1/mib.2018.35.3.761.

Arsad, S. (2010). Konservasi tanah dan air-edisi kedua. Bogor: IPB Press.

Aryani, R., \& Apriadi, T. (2018). Inventory of epiphytes aquatic microfungi in pond of tailing bauxite in Tanjungpinang, Bintan Island, Riau Islands Province. Omni-Akuatika, 14(3), 106-111. doi:10.20884/1.oa.2018.14.3.595.

Budiyanto, F., Arbi, U. Y., \& Suratno. (2019). Risk assessment on mercury concentration in six edible mollusks from Bintan Island, Indonesia. In International Conference on Biology and Applied Science (ICOBAS) (p. 040009). AIP Publishing. doi:10.1063/1.5115647.

Duvendack, M., Palmer-Jones, R., Copestake, J. G., Hooper, L., Loke, Y., \& Rao, N. (2011). What is the evidence of the impact of microfinance on the well-being of poor people? London: EPPI-Centre, Social Science Research Unit, Institute of Education, University of London.

Effendi, H. (2003). Telaah kualitas air: Bagi pengelolaan Sumber Daya dan Lingkungan Perairan. Yogyakarta: Kanisius.

Erfandi, D. (2017). Pengelolaan lansekap lahan bekas tambang: pemulihan lahan dengan pemanfaatan sumberdaya lokal (in-situ). Jurnal Sumberdaya Lahan, 11(2).

Hardiansyah, R. (2016). Analisis implementasi kebijakan pulau bintan sebagai Free Trade Zone (ftz) terhadap investasi di Bintan. Jurnal Benefita: Ekonomi Pembangunan, Manajemen Bisnis \& Akuntansi, 1(3), 163176. doi:10.22216/jbe.v1i3.882.

Hem, J. . (1989). Study and interpretation of chemical characteristics of natural waters (No. Paper 2254, 3rd ed.).

Irawan, A. B., \& Yudono, A. R. A. (2014). Studi kelayakan penentuan tempat pemrosesan akhir sampah (Tpa) di Pulau Bintan Propinsi Kepulauan Riau. Jurnal Ilmu Lingkungan, 12(1), 1-11.

Marganingrum, D. (2013). Manajemen sumberdaya air terpadu “Waduk Saguling” dalam rangka pengembangan 
SPAM regional KSN Cekungan Bandung. Institut Teknologi Bandung.

Marganingrum, D., Rusydi, A. F., Santoso, H., Makhfuddin, D., Wijaya, D. P., \& Nur, W. H. (2010). Konsep pengurangan kemiskinan berdasarkan analisis kemiskinan air. In Prosiding Geoteknologi LIPI (pp. 110134).

Marganingrum, D., \& Sudrajat, Y. (2018). Estimasi daya dukung sumber daya air di Pulau Kecil (Studi kasus Pulau Pari). Jurnal Wilayah Dan Lingkungan, 6(3), 164. doi:10.14710/jwl.6.3.164-182.

Masterson, J. P., Fienen, M. N., Thieler, E. R., Gesch, D. B., Gutierrez, B. T., \& Plant, N. G. (2013). Effects of sealevel rise on barrier island groundwater system dynamics - ecohydrological implications. Ecohydrology, 7, 1064-1071. doi:10.1002/eco.1442.

Meirinawati, H., \& Muchtar, M. (2017). Fluktuasi nitrat, fosfat dan silikat di perairan Pulau Bintan. Jurnal Segara, 13(3). doi:10.15578/segara.v13i3.6493.

Mensah, A. K. (2015). Role of revegetation in restoring fertility of degraded mined soils in Ghana: A review. International Journal of Biodiversity and Conservation, 72), 57-80. doi:10.5897/IJBC2014.0775.

Narulita, I., Djuwansyah, M.R. Sumawijaya, N. Marganingrum, D., Ningrum, W., \& Rahayu, R. (2018). Adaptasi dan mitigasi pengelolaan sumberdaya air terhadap pertumbuhan penduduk dan perubahan iklim di Pulau Kecil: Studi kasus Pulau Bintan. Bandung: LIPI Press.

Notodarmojo, S. (2005). Pencemaran tanah dan air tanah. Bandung: ITB Bandung.

Ochir, A., \& Davaa, G. (2011). Application of index analysis to evaluate the water quality of the Tuul River in Mongolia. Journal of Water Resource and Protection, 336050, 398-414. doi:10.4236/jwarp.2011.36050.

Prasetyo, B. H., \& Suriadikarta, D. A. (2006). Karakteristik, potensi, dan teknologi pengelolaan tanah ultisol untuk pengembangan pertanian lahan kering di Indonesia. Jurnal Litbang Pertanian, 25(2), 39-46.

Putra, R. D., Apriadi, T., Suryanti, A., Irawan, H., Said Raja'I, T., Yulianto, T., ... Koenawan, C. J. (2018). Preliminary study of heavy metal $(\mathrm{Zn}, \mathrm{Pb}, \mathrm{Cr}, \mathrm{As}, \mathrm{Cu}, \mathrm{Cd})$ contaminations on different soil level from postmining bauxite production for aquaculture. E3S Web of Conferences, 47, 02008. doi:10.1051/e3sconf/20184702008.

Ravikumar, P., Somashekar, R. K., \& Prakash, K. L. (2015). A comparative study on usage of Durov and Piper diagrams to interpret hydrochemical processes in groundwater from SRLIS river basin, Karnataka, India. Elixir International Journal, 80, 31073-31077.

Rusli, S., \& Fauzielly, L. (2016). Groundwater quality study of bauxite mining area, Bintan Land - Riau Islands Province. IJSRST, 2(6), 248-352.

Sallata, M. K. (2017). Pentingnya aplikasi teknik konservasi air dengan metode struktur fisik di Wilayah Hulu DAS. Buletin Eboni, 14(1), 47-62. doi:10.20886/buleboni.5095.

Santoso, D. H. (2015). Kajian daya dukung air di Pulau Bintan, Provinsi Kepulauan Riau. Jurnal Sains \& Teknologi Lingkungan, 71), 1-17. doi:10.20885/jstl.vol7.iss1.art1.

Sembiring, S. (2008). Sifat kimia dan fisik tanah pada areal bekas tambang bauksit di Pulau Bintan, Riau. Info Hutan, 5(2), 123-134.

Setiady, D., \& Faturachman, F. (2004). Tipe granit sepanjang pantai timur laut Pulau Batam dan pantai barat Pulau Bintan, Perairan Selat Batam. Jurnal Geologi Kelautan, 2(2), 9-14. doi:10.32693/jgk.2.2.2004.109.

Setiady, D., \& Faturachman, F. (2016). Tipe granit sepanjang pantai timur Pulau Batam dan Pantai Barat Pulau Bintan, Perairan Selat Batam Bintan. Jurnal Geologi Kelautan, 2(2).

Silvia, A. ., \& Safriani, M. (2018). Analisis potensi pemanenan air hujan dengan teknik rainwater harvesting untuk kebutuhan domestik. Jurnal Teknik Sipil Fakultas Teknik Universitas Teuku Umar, 4(1), 62-73.

Sukiyah, E., Isnaniawardhani, V., Sudradjat, A., \& Erawan, F. (2018). The geologic potentials of Riau Islands Province and its development design. Jurnal Perspektif Pembiayaan dan Pembangunan Daerah, 5(3), 181-190. doi:10.22437/ppd.v5i3.4554.

Tjasyono, B., \& Bannu, B. (2003). Dampak enso pada faktor hujan di Indonesia. Jurnal Matematika Dan Sains, $8(1), 15-22$.

Trenberth, K. E., Caron, J. M., Stepaniak, D. P., \& Worley, S. (2000). The evolution of ENSO and global atmospheric temperatures. J. Geophys. Res. Atmospheres. Retrieved from http://www.cgd.ucar.edu/cas/papers/jgr2001b/jgr2.html.

Utomo, E. ., Marganingrum, D., Rusydi, A. ., Purwoarminta, A., \& Ningrum, W. (2017). Rancang bangun pengelolaan sumberdaya airtanah untuk pengurangan risiko kekeringan akibat peningkatan cuaca ekstrim (perubahan iklim) di pulau-pulau kecil. Bandung. 